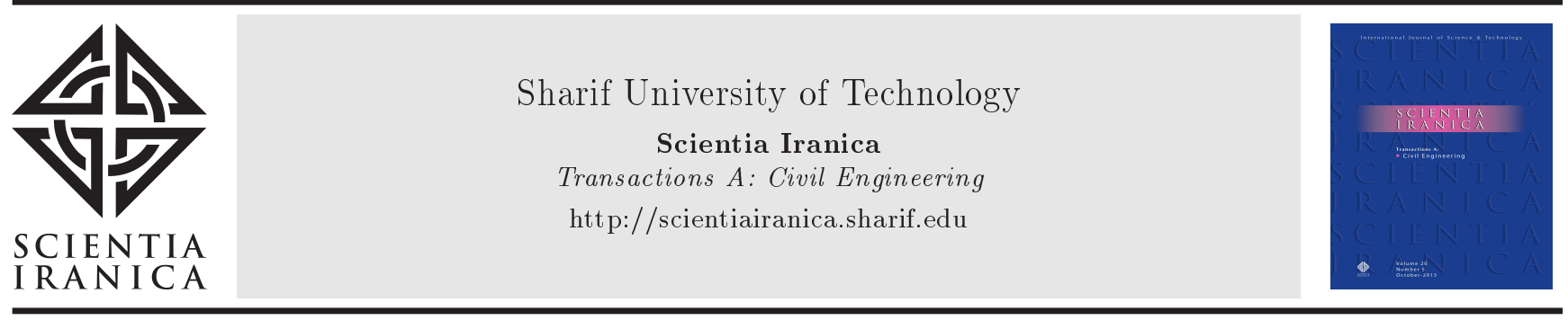

\title{
Uncertainty management in time estimation of construction projects: A systematic literature review and new model development
}

\author{
A. Naderpour ${ }^{a, *}$,J. Majrouhi Sardroud ${ }^{a, *}$, M. Mofid ${ }^{b}$, Y. Xenidis ${ }^{c}$, and \\ T. Pour Rostama \\ a. Department of Civil Engineering, Islamic Azad University, Central Tehran Branch, Tehran, Iran. \\ b. Department of Civil Engineering, Sharif University of Technology, Tehran, Iran. \\ c. Department of Civil Engineering, Aristotle University of Thessaloniki, Thessaloniki, Greece.
}

Received 17 June 2017; received in revised form 27 July 2017; accepted 14 August 2017

\section{KEYWORDS}

Time estimation;

Uncertainty;

Fuzzy logic;

Risk management;

Construction projects.

\begin{abstract}
Nowadays, the very low reliability of project planning in certainty-based approaches has led to the use of more intelligent methods for uncertainty management in construction projects. This systematic study aims to survey the methods which have been used to manage the uncertainties in time estimation of construction projects. A series of steps were undertaken during the review. The study was started with determining the purpose, selecting appropriate keywords, and reducing the selected papers using some criteria. A deeper analysis was carried out on the final paper that met the criteria for this review. The study was limited solely to papers referred to in six top online databases. It aimed to review how the papers had been distributed by a period of publishing, country, and the domains that the methods had been applied for. The result confirmed that uncertainties which affected any project were controlled by Risk Management and Fuzzy Logic based on probability and possibility theories. Finally, a hybrid method for uncertainty management in project scheduling was proposed. The result of the implementation of this method in the construction project of Iranian Gas Company showed that the proposed method increased the accuracy of time estimation by about 8 to 24 percent.
\end{abstract}

(C) 2019 Sharif University of Technology. All rights reserved.

\section{Introduction}

Nowadays, the importance of time management in the field of construction projects is well known. Time management can be effective in a project when the project schedule is based on reasonable and comprehensive time estimation. Uncertainties that affect the project are based on two theories: probability and possibility.

*. Corresponding authors.

E-mail addresses: abas.naderpour@gmail.com (A.

Naderpour); j.majrouhi@iauctb.ac.ir (J. Majrouhi Sardroud)

doi: $10.24200 /$ sci.2017.4605
This paper aims to survey the methods which have been used to manage the uncertainties in time estimation of construction projects and proposes a comprehensive method for uncertainty management in construction projects scheduling. A series of steps are undertaken during the review according to research methodology.

\section{Research methodology}

In this paper, the literature related to uncertainty management in construction project scheduling is reviewed, comprehensively, by documents referred to in six main scientific online databases, namely Science Direct (Elsevier), ASCE Online Library, Taylor and 


\begin{tabular}{|c|c|c|c|}
\hline \multicolumn{4}{|c|}{ Step 1: Paper selection by Key Words / Preliminary Analysis (Up to 31 March 2017) } \\
\hline \multicolumn{4}{|c|}{$\downarrow$} \\
\hline Elsevier $=859$ & \multicolumn{2}{|c|}{ Taylor \& Francis $=2389$} & Springer $=1141$ \\
\hline ASCE $=2512$ & \multicolumn{2}{|c|}{ John Wiley = 1859} & Hindawi $=\mathbf{4 4 0}$ \\
\hline \multicolumn{4}{|c|}{$\downarrow$} \\
\hline \multicolumn{4}{|c|}{ Step 2: Identified Selected Papers by Peer Analysis } \\
\hline$\downarrow$ & \multicolumn{2}{|c|}{$\frac{1}{t}$} & $\frac{1}{t}$ \\
\hline Elsevier & \multicolumn{2}{|c|}{ Taylor \& Francis } & Springer \\
\hline Identified Papers $=88$ & \multicolumn{2}{|c|}{ Identified Papers $=23$} & Identified Papers $=34$ \\
\hline Fuzzy Approach $=22$ & \multicolumn{2}{|c|}{ Fuzzy Approach $=4$} & Fuzzy Approach $=13$ \\
\hline Contingency Approach $=66$ & \multicolumn{2}{|c|}{ Contingency Approach $=19$} & Contingency Approach $=21$ \\
\hline Risk Management $=59$ & \multicolumn{2}{|c|}{ Risk Management $=16$} & Risk Management $=16$ \\
\hline Other Approaches = 7 & \multicolumn{2}{|c|}{ Other Approaches $=3$} & Other Approaches $=5$ \\
\hline & & \\
\hline ASCE & \multicolumn{2}{|c|}{ John Wiley } & Hindawi \\
\hline Identified Papers $=81$ & \multicolumn{2}{|c|}{ Identified Papers $=12$} & Identified Papers $=4$ \\
\hline Fuzzy Approach = 21 & \multicolumn{2}{|c|}{ Fuzzy Approach $=6$} & Fuzzy Approach $=4$ \\
\hline Contingency Approach $=60$ & \multicolumn{2}{|c|}{ Contingency Approach $=6$} & Contingency Approach $=0$ \\
\hline Risk Management $=41$ & \multicolumn{2}{|c|}{ Risk Management $=6$} & Risk Management $=0$ \\
\hline Other Approaches $=19$ & \multicolumn{2}{|c|}{ Other Approaches $=0$} & Other Approaches $=0$ \\
\hline \multicolumn{4}{|c|}{ Step 3: Discussion, Summary and Conclusion } \\
\hline \multicolumn{2}{|c|}{ Fuzzy Approach $=70$} & \multicolumn{2}{|c|}{ Risk Management Approach $=172$} \\
\hline \multicolumn{2}{|c|}{ Publication Years: 1984 - 2017} & \multicolumn{2}{|c|}{ Number of Authors Countries: 35} \\
\hline \multicolumn{4}{|c|}{ Uncertainty Approaches Distribution: Fuzzy $=29 \%$, Risk=57\%, Others $=14 \%$} \\
\hline \multicolumn{4}{|c|}{$\begin{array}{l}\text { Application fields: Schedule Delay and Trip Time Variability, quay crane scheduling, automation } \\
\text { of location-based earthwork scheduling in road construction projects, Project Delivery Method } \\
\text { Selection for Highway Projects, Manufacturing Companies in Turkey, causal structure of time } \\
\text { buffer allocation, a BOT highway project application, Steelmaking-Continues casting Production. } \\
\text { Other Contingency Approach: Mathematical Methods, Heuristic and Meta Heuristic Algonthms, } \\
\text { Genetic Algonithm, Neural Network, Linear Programming, Markov Chain, Monte Carlo Simulation. }\end{array}$} \\
\hline
\end{tabular}

Figure 1. Research methodology diagram.

Francis, Springer journal collection, Hindawi, and John Wiley online databases.

Following to the diagram presented in Figure 1, the first publications in the area up to March 31, 2017 are reviewed. Three groups of combinations of the methods devoted to calculating the relative significance of criteria and ranking of alternatives can be identified:

1. Uncertainty + project scheduling + construction management;

2. Project stochastic scheduling + uncertainty + comprehensive time management;
3. Project scheduling methods + artificial intelligence + metaheuristic and hybrid methods.

There are 9236 publications on the topic of uncertainty referred to in the mentioned six databases. Figure 1 shows the research methodology diagram.

\section{Detailed review results}

The result of this research indicates that the methods of uncertainty managing in construction project scheduling are divided into three approaches: fuzzy, risk, and 


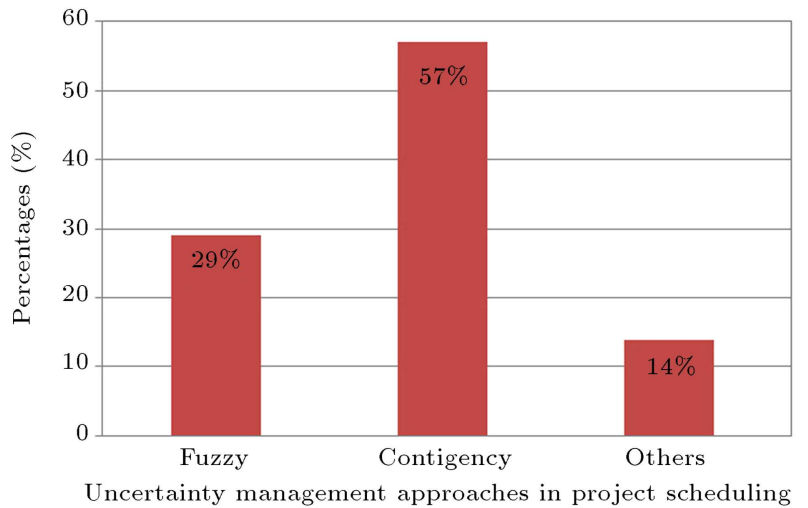

Figure 2. Statistical view of uncertainty management approaches in project scheduling.

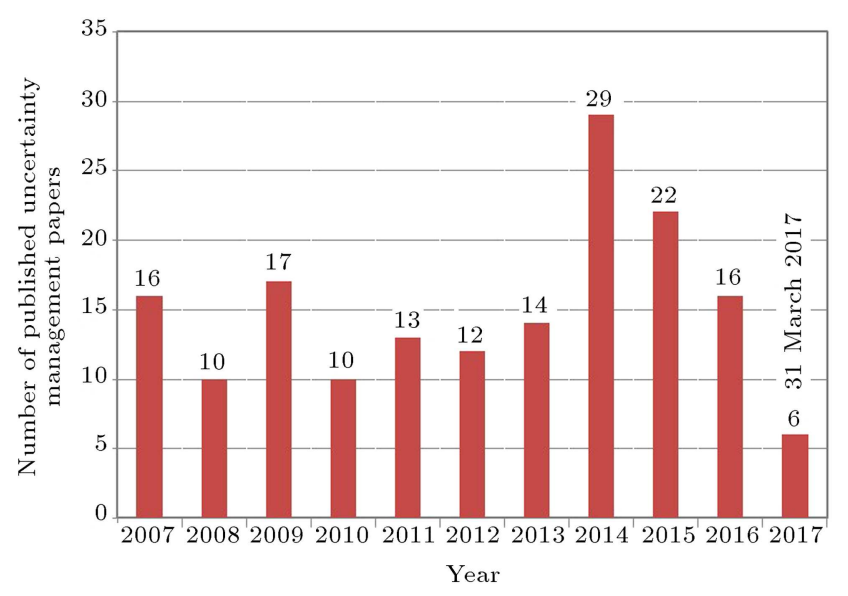

Figure 3. Researches in the last decade on uncertainty management in project scheduling.

other mathematical and heuristic approaches. Figure 2 shows the distribution of the mentioned approaches.

Statistical view of published papers with the title of uncertainty management in construction project scheduling in the last decade (from 2007 up to March 31, 2017) is shown in Figure 3.

Also, the comparison of published papers with the title of uncertainty management by fuzzy and risk in the last decade is shown in Figure 4. According to the result of this research, about 250 authors from 35 countries have contributed to improving the application of uncertainty management in construction projects. Figure 5 indicates the top ten countries that have the most related papers about this research subject. As it can be seen in this figure, USA, China, and Canada have the most researches. Also, a statistical view of the journals with the most papers about uncertainty management in construction project scheduling is shown in Figure 6. According to this figure, the Journal of Construction Engineering Management (ASCE) with 40 related papers is the top journal in this subject of research.

It is worth mentioning that 230 out of 242 selected

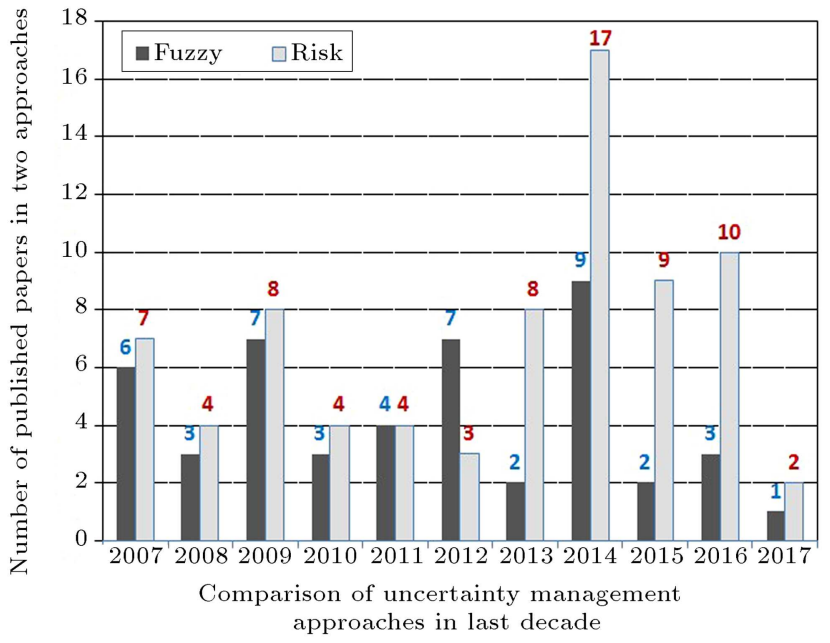

Figure 4. Comparison of uncertainty management approaches in the last decade.

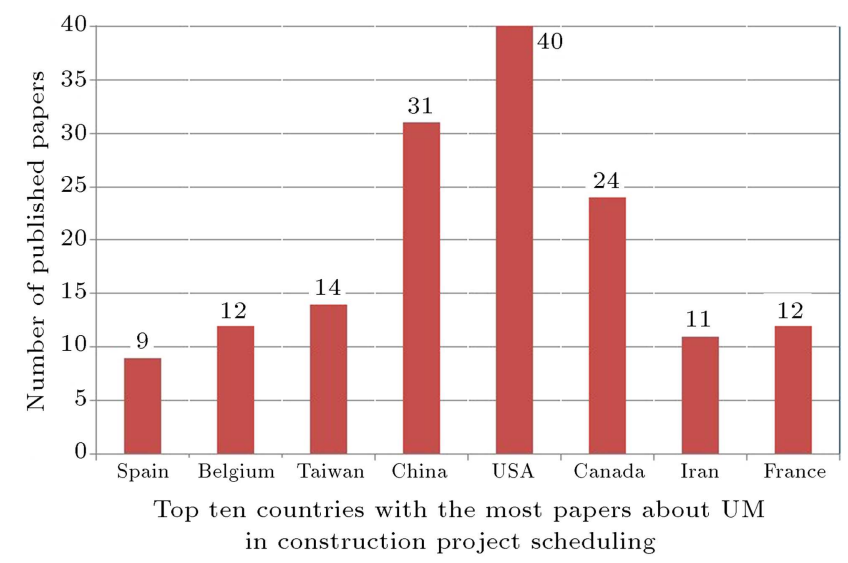

Figure 5. Countries with the most papers on uncertainty management in project scheduling.

papers have only described the theory and only 12 papers are applications, as explained in Table 1. Also, 6 papers have hybrid approaches and the combinations of their approaches are described in Table 2.

In the following, Tables 3,4 , and 5 show the selected research papers according to the mentioned 3 approaches of uncertainty management in construction project scheduling. According to the result of this review, most papers that use fuzzy approach have concentrated on possible uncertainty management in project scheduling, and the papers with risk management approach have concentrated on managing the probable uncertainties. Also, other mathematical, heuristic, and hybrid methods have concentrated on managing the probable uncertainties. As a result, it is worth mentioning that the best approach to managing possible uncertainties is fuzzy method, because in fuzzy method, uncertainty of project activities remains in the whole calculation stages; but in other mathematical algorithms and artificial intelligence methods, 
Table 1. List of the application papers with the title of uncertainty management in project scheduling.

\begin{tabular}{|c|c|c|}
\hline Considered issues and problems & Applied method & Author(s), publishing year \\
\hline $\begin{array}{l}\text { Presenting a scheduling algorithm } \\
\text { for the real-world steelmaking-continuous } \\
\text { casting production }\end{array}$ & Mathematical heuristic method & Jiang et al., 2016 [1] \\
\hline $\begin{array}{l}\text { GA approach for the quay crane } \\
\text { scheduling under uncertainty }\end{array}$ & Genetic algorithm method & Al-Dhaheri et al., 2016 [2] \\
\hline $\begin{array}{l}\text { GA approach for remanufacturing } \\
\text { process planning and scheduling }\end{array}$ & Genetic algorithm method & Zhang et al., 2015 [3] \\
\hline $\begin{array}{l}\text { Robust algorithm for scheduling } \\
\text { of manufacturing tasks }\end{array}$ & Simulated Annealing (SA) algorithm & Józefezyk \& Thomas, 2007 [4] \\
\hline $\begin{array}{l}\text { Modeling completion risk using } \\
\text { stochastic critical path: a } \\
\text { BOT highway project application }\end{array}$ & A BOT highway project application & Kokkaew \& Chiara, 2010 [5] \\
\hline $\begin{array}{l}\text { A stochastic dynamic programming } \\
\text { based model for uncertain planning }\end{array}$ & Planning of e-manufacturing system & Li et al., $2009[6]$ \\
\hline $\begin{array}{c}\text { Critical risk factors in project delivery of } \\
\text { highway projects }\end{array}$ & Risk management & Tran \& Molenaar, 2012 [7] \\
\hline $\begin{array}{l}\text { Action-based union of the } \\
\text { temporal opposites and elastic } \\
\text { activity network in scheduling }\end{array}$ & $\begin{array}{l}\text { Automation of location-based } \\
\text { earthwork scheduling in road } \\
\text { construction projects }\end{array}$ & Yagi \& Arai, 2006 [8] \\
\hline $\begin{array}{l}\text { Simulation multi-agent approach } \\
\text { for scheduling modular construction }\end{array}$ & Scheduling modular construction & Taghaddos et al., 2012 [9] \\
\hline $\begin{array}{c}\text { Uncertainty modeling in } \\
\text { development projects (case study) }\end{array}$ & Manufacturing companies in Turkey & Özdamar \& Alanya, 2001 [10] \\
\hline $\begin{array}{l}\text { Integrating the mean-variance and } \\
\text { scheduling approaches to allow for } \\
\text { schedule delay and trip time } \\
\text { variability under uncertainty }\end{array}$ & Schedule delay and trip time variability & Li et al., 2016 [11] \\
\hline $\begin{array}{c}\text { Robust multi-objective maintenance } \\
\text { planning of deteriorating bridges against } \\
\text { uncertainty in performance }\end{array}$ & $\begin{array}{c}\text { Maintenance planning of deteriorating } \\
\text { bridges against uncertainty in } \\
\text { performance model }\end{array}$ & Ok et al., 2013 [12] \\
\hline
\end{tabular}

certainty based tools such as learning rules in neural networks method reduce the mentioned uncertainty in calculation stages and this leads to reduction in time estimation accuracy. Also, the best way to manage probable uncertainties is the implementation of risk management in construction projects. Therefore, a comprehensive way of managing uncertainties in construction project scheduling is a method of dual approach. In the following, a hybrid model is proposed to solve this problem. It is worth mentioning that the 


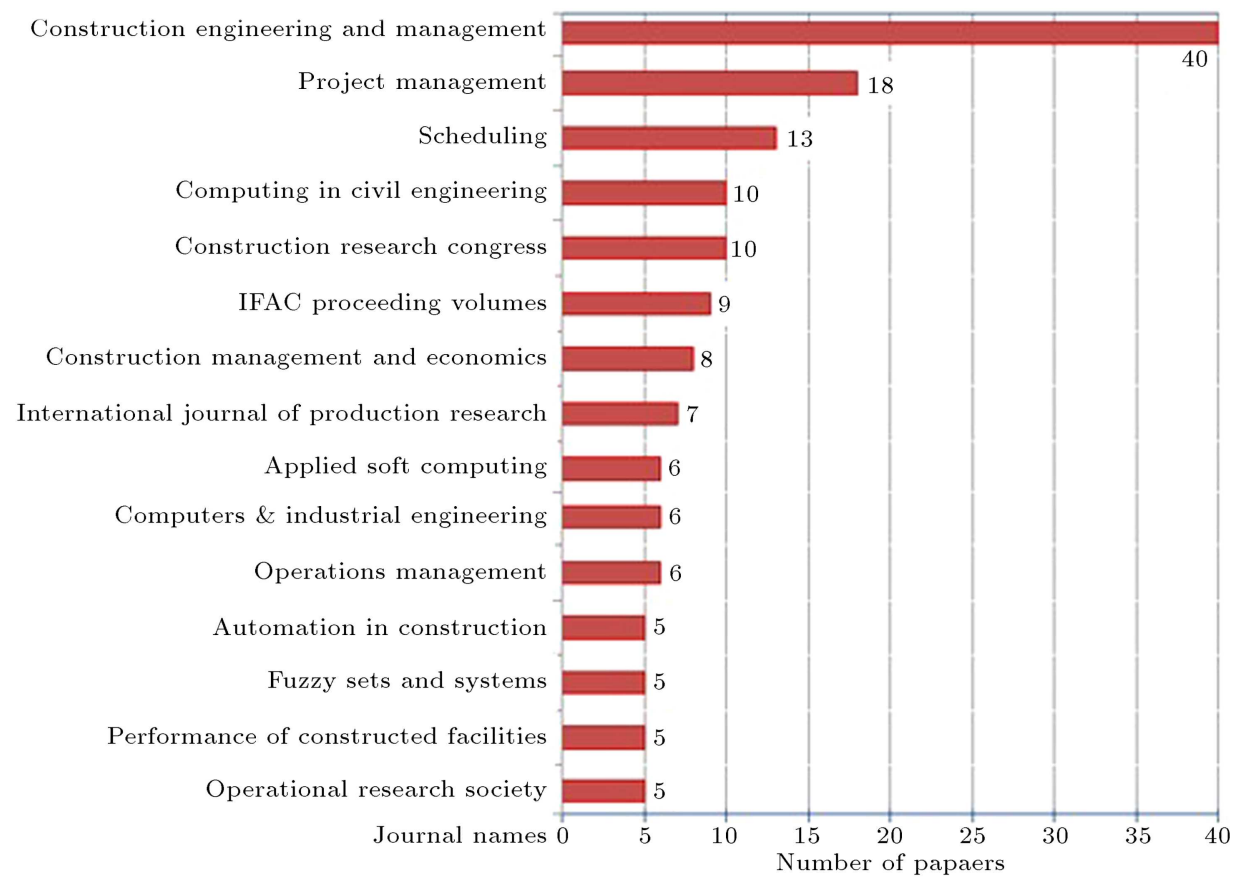

Figure 6. Journals with the most papers on uncertainty management in project scheduling.

Table 2. List of the hybrid papers with the title of uncertainty management in project scheduling.

\begin{tabular}{ccc}
\hline Considered issues and problems & Applied method & Author(s), publishing year \\
\hline $\begin{array}{c}\text { A new fuzzy TOPSIS hybrid method for green } \\
\text { supplier selection using fuzzy time function }\end{array}$ & Fuzzy TOPSIS hybrid method & $\begin{array}{c}\text { Arshadi Khamseh \& Mahmoodi., } \\
\text { A new time-invariant fuzzy time series }\end{array}$ \\
$\begin{array}{c}\text { forecasting method based on genetic algorithm } \\
\text { Measuring duration of the risk-associated } \\
\text { activity: a fuzzy set theory application }\end{array}$ & Fuzzy + GA & Eğrioğlu, 2012 [14] \\
$\begin{array}{c}\text { Fuzzy neural network-based rescheduling decision } \\
\text { mechanism for semiconductor manufacturing }\end{array}$ & Fuzzy + neural network & Ock \& Han, 2010 [15] \\
$\begin{array}{c}\text { Fuzzy flexible resource constrained } \\
\text { project scheduling based on genetic algorithm }\end{array}$ & Fuzzy + GA & Zhang et al., 2014 [16] \\
$\begin{array}{c}\text { A GA-based fuzzy optimal model } \\
\text { for construction time-cost trade-off }\end{array}$ & & GA + Fuzzy $2014[17]$
\end{tabular}

proposed model has been implemented in construction projects of Iranian gas refineries; the related result is described after the model description.

\section{A new proposed model for managing uncertainties in construction project scheduling}

According to the result of the systematic review in this paper, a new model based on the comprehensive integration of possible and probable uncertainty manage- ment is proposed for optimum scheduling of construction projects. Figure 7 indicates the diagram of the proposed model. In fact, this model is an integration of risk management and fuzzy expert systems to manage uncertainties in construction projects scheduling.

\section{Implementation of the proposed model in SGPC construction projects}

For implementing the proposed model, at first, two professional questionnaires were distributed among 200 


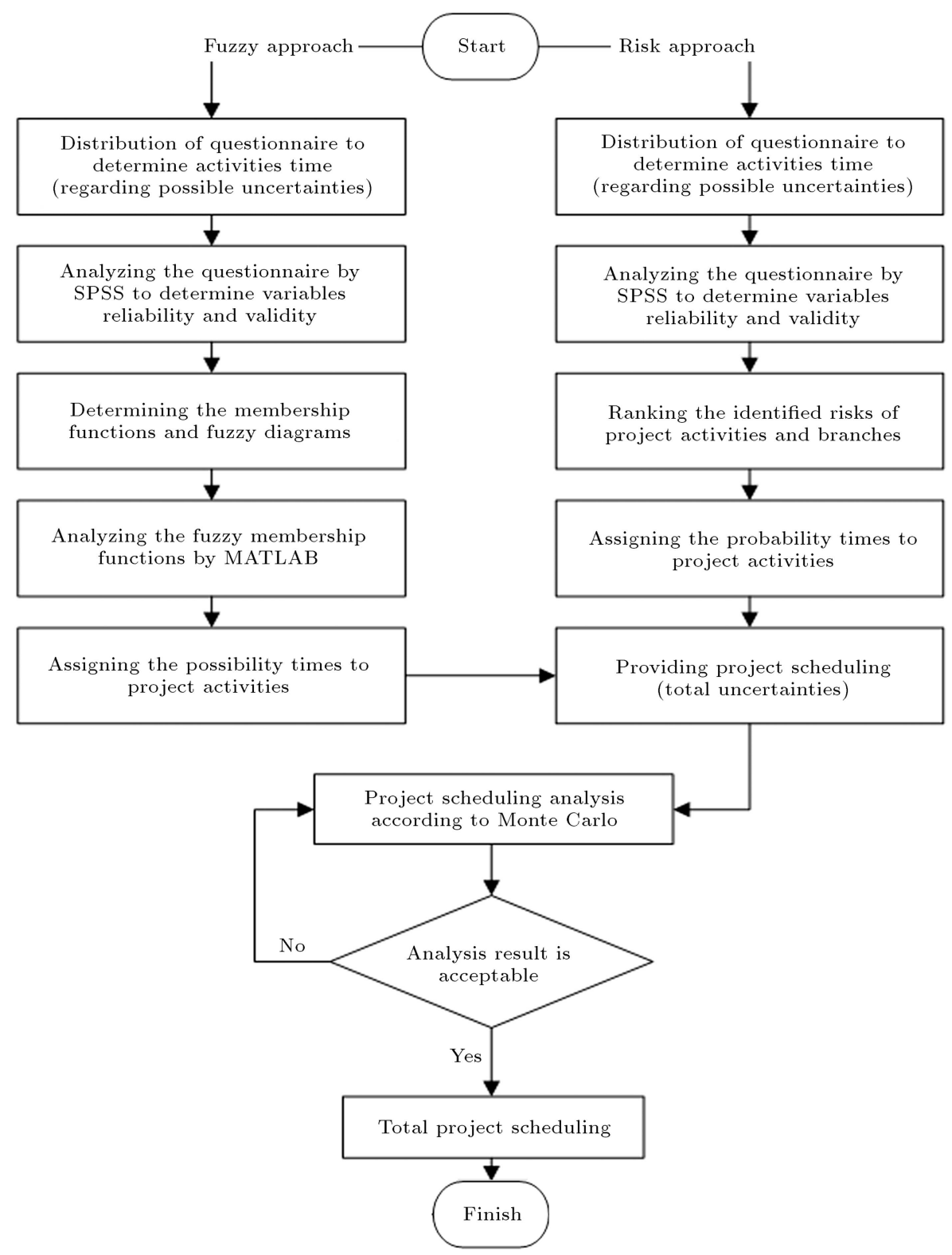

Figure 7. Diagram of the proposed model.

experts of a professional team, which were selected by the staff of 70 contractors, consultants, and client companies. The first questionnaire was designed to identify effective factors such as site organization, weather, labor skills, and quality of equipment in doing project activities. Then, the obtained linguistic variables were translated into mathematical measures. For instance, the questionnaire designed for painting activity is presented in Table 6 . As it can be seen in the mentioned table, the values of the linguistic variables were classified into five types. As shown in Table 6 , seven factors were considered to estimate the time of painting activity. To examine the reliability of the questionnaire, data analysis was done by SPSS. The results showed that factors 2,3 , and 7 did not have considerable influence on the timing of painting activity (Table 7). Therefore, these factors were eliminated, and calculations were repeated. In the new analysis, the index rose to 0.938 , which was desirable. Table 8 shows the result of the second analysis. The main factors of painting activity were climatic condition, quality of paint, availability of skilled workers, and rate of surface opening.

Also, the result of correlation survey by Pearson coefficient indicated that the mentioned factors correlated (Table 9). Consequently, the volume of statistical society was enough, and there was no need for an extension.

In the next step, the second questionnaire, which was related to estimation of activity durations, was 
Table 3. Specifications of the most important fuzzy approach papers.

\begin{tabular}{|c|c|}
\hline Considered issues and problems & Author(s), publishing year \\
\hline Real-time task scheduling by fuzzy method & Muhuri \& Shukla, 2017 [19] \\
\hline Flexible scheduling model by fuzzy method & Dubios et al., 2003 [20] \\
\hline $\begin{array}{l}\text { Linguistic approach to non-identical parallel } \\
\text { processor scheduling with fuzzy processing times }\end{array}$ & Geyik \& Elibal, 2017 [21] \\
\hline $\begin{array}{l}\text { Using trapezoidal intuitionist fuzzy number to find } \\
\text { optimized path in a schedule network }\end{array}$ & Jayagowri \& Ramani, 2014 [22] \\
\hline $\begin{array}{l}\text { A new fuzzy TOPSIS-TODIM hybrid method for } \\
\text { green supplier selection using fuzzy time function }\end{array}$ & Arshadi \& Mahmoodi, 2014 [13] \\
\hline Fuzzy networked systems design by scheduling restrictions & Benítez-Pérez et al., 2012 [23] \\
\hline $\begin{array}{l}\text { A new time-invariant fuzzy time series forecasting } \\
\text { method based on genetic algorithm }\end{array}$ & Eğrioğlu, 2012 [24] \\
\hline $\begin{array}{l}\text { Fuzzy multi-objective optimization of finance-based } \\
\text { scheduling for construction projects with uncertainties in cost }\end{array}$ & Afshar \& Fathi, 2009 [25] \\
\hline $\begin{array}{l}\text { An integration of the fuzzy reasoning technique and } \\
\text { optimization method in construction project } \\
\text { management decision-making }\end{array}$ & Lam et al., 2001 [26] \\
\hline $\begin{array}{l}\text { Some design issues in cellular manufacturing using } \\
\text { the fuzzy programming approach }\end{array}$ & Shanker \& Vart, 1999 [27] \\
\hline Project scheduling using fuzzy set concepts & Ayyub \& Haldar, 1984 [28] \\
\hline Fuzzy optimal model for resource-constrained construction scheduling & Leu et al., 1999 [29] \\
\hline Fuzzy project scheduling & Bonnal et al., 2004 [30] \\
\hline Fuzzy approach for activity delay analysis and schedule updating & Oliveros \& Fayek, 2005 [31] \\
\hline Fuzzy scheduling method for projects with repeating activities & Maravas \& Pantouvakis, 2010 [32] \\
\hline $\begin{array}{l}\text { A process for the estimation of the duration of activities in } \\
\text { fuzzy project scheduling }\end{array}$ & Maravas \& Pantouvakis, 2011 [33] \\
\hline $\begin{array}{l}\text { Emergency scheduling model of multi-objective-to-resource } \\
\text { under uncertain requirements }\end{array}$ & Xiong and Wang 2014 [34] \\
\hline $\begin{array}{l}\text { Inexact fuzzy chance-constrained nonlinear programming approach to } \\
\text { crop water allocation under precipitation variation } \\
\text { and sustainable development }\end{array}$ & Guo et al., 2013 [35] \\
\hline Estimating precipitation impacts for scheduling & Smith \& Hancher, 1989 [36] \\
\hline Network resource allocation with support of a fuzzy system & Chang et al., 1990 [37] \\
\hline $\begin{array}{l}\text { Scheduling demand-responsive transportation vehicles using } \\
\text { fuzzy-set theory }\end{array}$ & Kikuchi \& Donnelly, 1992 [38] \\
\hline
\end{tabular}


Table 3. Specifications of the most important fuzzy approach papers (continued).

\begin{tabular}{|c|c|}
\hline Considered issues and problems & Author(s), publishing year \\
\hline Fuzzy-set approach to optimizing sludge application land selection & Crump et al., 1993 [39] \\
\hline Application of fuzzy linear programming in civil engineering & Kumar et al., $2000[40]$ \\
\hline Forecasting project status by using fuzzy logic & Li et al., $2006[41]$ \\
\hline $\begin{array}{l}\text { Construction project scheduling using fuzzy mathematical } \\
\text { models and critical path method }\end{array}$ & Castro-Lacouture et al., 2009 [42] \\
\hline $\begin{array}{l}\text { Multi-objective evolutionary finance-based scheduling: } \\
\text { entire projects' portfolio }\end{array}$ & Abido \& Elazouni, 2010 [43] \\
\hline $\begin{array}{l}\text { New approach to modelling material-related } \\
\text { problems contributing to project delays using rotational fuzzy set }\end{array}$ & Al-Humaidi \& Tan, 2011 [44] \\
\hline Possibility moments for the task duration in fuzzy PERT & Chrysafis \&Papadopoulos, 2014 [45] \\
\hline A fuzzy discrete event simulation for construction applications & Sadeghi et al., $2016[46]$ \\
\hline $\begin{array}{l}\text { A process for the estimation of the duration of activities } \\
\text { in fuzzy project scheduling }\end{array}$ & Maravas \& Pantouvakis, $2011[47]$ \\
\hline $\begin{array}{l}\text { Application of fuzzy sets for remaining life assessment } \\
\text { of corrosion affected reinforced concrete bridge girders }\end{array}$ & Anoop \& Balaji Rao, 2007 [48] \\
\hline $\begin{array}{c}\text { Fuzzy logic approach to activity delay analysis and schedule updating - } \\
\text { Journal of Construction Engineering and Management }\end{array}$ & Oliveros \& Fayek, 2005 [49] \\
\hline Fuzzy optimal model for resource-constrained scheduling & Leu and Hung, $2002[50]$ \\
\hline Robustness measure for fuzzy maintenance activities schedule & Marmier et al., 2007 [51] \\
\hline $\begin{array}{l}\text { Location of cross-docking centers and vehicle routing scheduling } \\
\text { under uncertainty: a fuzzy possibilistic programming model }\end{array}$ & Mousavi et al., 2014 [52] \\
\hline Modeling project time-cost trade-off in fuzzy random environment & Ke \& Ma, $2014[53]$ \\
\hline $\begin{array}{l}\text { Procurement scheduling for complex projects with fuzzy } \\
\text { activity durations and lead times }\end{array}$ & Dixit et al., $2014[54]$ \\
\hline $\begin{array}{c}\text { Project scheduling under uncertainty using fuzzy modeling } \\
\text { and solving techniques }\end{array}$ & Masmoudi and Hait $2013[55]$ \\
\hline $\begin{array}{l}\text { Intelligent timetable evaluation using fuzzy AHP, expert } \\
\text { systems with applications }\end{array}$ & Isaai et al., $2011[56]$ \\
\hline $\begin{array}{l}\text { Real-time scheduling of periodic tasks with } \\
\text { processing times and deadlines as parametric fuzzy numbers }\end{array}$ & Muhuri \& Shukla, 2009 [57] \\
\hline Fuzzy hierarchical production planning & Torabi et al., 2010 [58] \\
\hline $\begin{array}{l}\text { MRP with flexible constraints: a fuzzy mathematical } \\
\text { programming approach }\end{array}$ & Mula et al., $2006[59]$ \\
\hline
\end{tabular}


Table 3. Specifications of the most important fuzzy approach papers (continued).

\begin{tabular}{|c|c|}
\hline Considered issues and problems & Author(s), publishing year \\
\hline Material requirement planning with fuzzy constraints and fuzzy coefficients & Mula et al., 2007 [60] \\
\hline $\begin{array}{l}\text { Fuzzy critical chain method for project scheduling } \\
\text { under resource constraints and uncertainty }\end{array}$ & Long \& Ohsato, 2008 [61] \\
\hline Fuzzy project scheduling system for software development & Hapke et al., 1994 [62] \\
\hline $\begin{array}{l}\text { A fuzzy project scheduling approach to minimizing } \\
\text { schedule risk for product development }\end{array}$ & Wang , $2002[63]$ \\
\hline Fuzzy logic-based secure and fault tolerant job scheduling & Wang et al., 2007 [64] \\
\hline $\begin{array}{l}\text { Real-time task scheduling with fuzzy uncertainty } \\
\text { in processing times and deadlines }\end{array}$ & Muhuri \& Shukla, 2008 [65] \\
\hline $\begin{array}{l}\text { Fuzzy resource-constrained project scheduling } \\
\text { using taboo search algorithm }\end{array}$ & Atli \& Kahraman, 2012 [66] \\
\hline $\begin{array}{l}\text { The fuzzy project scheduling problem with minimal } \\
\text { generalized precedence relations }\end{array}$ & Ponz-Tienda et al., 2015 [67] \\
\hline Estimating risk adjusted cost or schedule using fuzzy logic & Bellagamba, 1999 [68] \\
\hline Fuzzy Monte Carlo simulation and risk assessment in construction & Sadeghi et al., 2010 [69] \\
\hline $\begin{array}{l}\text { Computer-aided project duration forecasting subjected } \\
\text { to the impact of rain }\end{array}$ & Guo, $2000[70]$ \\
\hline Survey of fuzzy shop scheduling & Behnamian, 2016 [71] \\
\hline $\begin{array}{l}\text { Resource preprocessing and optimal task scheduling } \\
\text { in cloud computing environments }\end{array}$ & Liu et al., 2015 [72] \\
\hline Fuzzy due-date scheduling problem with fuzzy processing time & Itoh \& Ishii, 1999 [73] \\
\hline Survey of fuzzy shop scheduling & Behnamian, 2016 [74] \\
\hline $\begin{array}{l}\text { Demand uncertainty in construction supply chains: } \\
\text { a discrete event simulation study }\end{array}$ & Vidalakis et al., 2013 [75] \\
\hline $\begin{array}{l}\text { A new approach to solving time-cost trade-off problem with } \\
\text { fuzzy decision variables }\end{array}$ & Ghazanfari et al., 2009 [76] \\
\hline $\begin{array}{l}\text { A theoretical and practical framework for scheduling in a } \\
\text { stochastic environment }\end{array}$ & Bidot et al., 2009 [77] \\
\hline A fuzzy set approach to activity scheduling for product development & Wang, $1999[78]$ \\
\hline $\begin{array}{l}\text { Project scheduling problem for software development } \\
\text { with random fuzzy activity duration times }\end{array}$ & Huang et al., 2009 [79] \\
\hline Two uncertain empirical models for project scheduling problem & Ding \& Zhu, 2015 [80] \\
\hline Criticality analysis of activity networks under interval uncertainty & Fortin et al., 2010 [81] \\
\hline
\end{tabular}


Table 4. Specifications of the most important authors of papers with risk management approach.

\begin{tabular}{|c|c|c|c|}
\hline No. & Author(s), publishing year & No. & Author(s), publishing year \\
\hline 1 & Keller \& Bayraksan, 2009 [82] & 51 & Mawlana \& Hammad, 2015 [131] \\
\hline 2 & Fernandez et al., 1998 [83] & 52 & Mínguez \& Conejo, 2011 [132] \\
\hline 3 & Reed \& Knight, 2013 [84] & 53 & Likhachev \& Stentz, 2009 [133] \\
\hline 4 & Küchler \& Vigerske, 2010 [85] & 54 & Öztaş \& Ökmen, 2005 [134] \\
\hline 5 & Kang et al., 2011 [86] & 55 & Zwikael \& Sadeh, 2007 [135] \\
\hline 6 & Poshdar et al., 2016 [87] & 56 & Li, $2015[136]$ \\
\hline 7 & Shahtaheri et al., 2016 [88] & 57 & Zhang et al., 2017 [137] \\
\hline 8 & De Marco et al., 2015 [89] & 58 & Ryu et al., 2015 [138] \\
\hline 9 & $\mathrm{Li}$ and $\mathrm{Xu} 2014[90]$ & 59 & Dehghan \& Ruwanpura, 2011 [139] \\
\hline 10 & El-Kholy, 2013 [91] & 60 & Yang \& Chang, 2005 [140] \\
\hline 11 & Yang et al., 2013 [92] & 61 & Tabrizi \& Ghaderi., 2016 [141] \\
\hline 12 & Perrenoud et al., 2014 [93] & 62 & Jozefezyk \& Thomas, 2007 [4] \\
\hline 13 & Park et al., 2014 [94] & 63 & AlNasseri \& Aulin, 2015 [142] \\
\hline 14 & Khamooshi \& Cioffi, 2012 [95] & 64 & Herroelen \& Leus, 2004 [143] \\
\hline 15 & Tran \& Molenaar, $2012[7]$ & 65 & Zilberstein \& Mouaddib, 2000 [144] \\
\hline 16 & Dikmen et al., 2012 [96] & 66 & Gálvez \& Capuz-Rizo, 2016 [145] \\
\hline 17 & Barraza, 2010 [97] & 67 & Lawrence \& Sewell, 1997 [146] \\
\hline 18 & Mohamed et al., 2009 [98] & 68 & Kadipasaoglu \& Sridharan, 1995 [147] \\
\hline 19 & Schatteman et al., 2008 [99] & 69 & Gong \& Rowings, 1995 [148] \\
\hline 20 & Ökmen \& Öztaş, 2008 [100] & 70 & Rahmani et al., 2013 [149] \\
\hline 21 & Feng et al., 2000 [101] & 71 & Shah, 2014 [150] \\
\hline 22 & Mulholland \& Christian, 1999 [102] & 72 & Izák et al., 2010 [151] \\
\hline 23 & Creemers, 2015 [103] & 73 & Izák et al., 2008 [152] \\
\hline 24 & Rostami et al., 2017 [104] & 74 & Tang \& Grubbström, 2002 [153] \\
\hline 25 & Fu et al., 2015 [105] & 75 & Herroelen \& Leus, 2005 [154] \\
\hline 26 & Zhu et al., 2007 [106] & 76 & Wang et al., 2017 [155] \\
\hline 27 & Lee et al., 2015 [107] & 77 & Chang et al., 2013 [156] \\
\hline 28 & Choi et al., 2007 [108] & 78 & Arashpour et al., 2016 [157] \\
\hline 29 & Zafra-Cabeza et al., 2005 [109] & 79 & Fiedler, 1987 [158] \\
\hline 30 & Pontrandolfo, 2000 [110] & 80 & Bushuyev \& Sochnev, 1999 [159] \\
\hline 31 & Gong, 1997 [111] & 81 & Zhao \& Lee, 1993 [160] \\
\hline 32 & Mahjoub and Pecero Sánchez 2011 [112] & 82 & Koo et al., 2011 [161] \\
\hline 33 & Ahuja \& Nandakumar, 1985 [113] & 83 & Sridharan \& LaForge, 1998[162] \\
\hline 34 & Bruun, 1992 [114] & 84 & Alzraiee et al., 2015 [163] \\
\hline 35 & Lansey \& Menon, 1993 [115] & 85 & Acebes et al., 2014 [164] \\
\hline 36 & Ben-Haim \& Laufer, 1998 [116] & 86 & Van Marrewijk et al., 2008 [165] \\
\hline 37 & Guillaumot et al., 2003 [117] & 87 & Raturi et al., 1990 [166] \\
\hline 38 & Moussa et al., 2007 [118] & 88 & Garaix et al., 2013 [167] \\
\hline 39 & Vaziri et al., 2007 [119] & 89 & Demeulemeester \& Herroelen, 2007 [168] \\
\hline 40 & Bocchini \& Frangopol, 2011 [120] & 90 & Golizadeh et al., 2016 [169] \\
\hline 41 & Nguyen et al., 2013 [121] & 91 & Vujanic et al., 2016 [170] \\
\hline 42 & Ma et al., $2014[122]$ & 92 & Lamas \& Demeulemeester, 2016 [171] \\
\hline 43 & Russell et al., 2015 [123] & 93 & Jeang, 2015 [172] \\
\hline 44 & Wang et al., 2014 [124] & 94 & Ke and Liu, 2015 [173] \\
\hline
\end{tabular}


Table 4. Specifications of the most important authors of papers with risk management approach (continued).

\begin{tabular}{cccc}
\hline No. & Author (s), publishing year & No. & Author (s), publishing year \\
\hline 45 & Ji \& Yao, 2014 [125] & 95 & Shtub, 1986 [174] \\
46 & Gan \& Xu, 2013 [126] & 96 & Lambrechts et al., 2008 [175] \\
47 & Russell et al., 2014 [127] & 97 & Chen \& Huang, 2006 [176] \\
48 & Wang et al., 2016 [128] & 98 & Gil et al., 2004 [177] \\
49 & Li et al., 2016 [129] & 99 & Abdeddaïm et al., 2003 [178] \\
50 & Artigues et al., 2013 [130] & 100 & Zhu et al., 2005 [179]
\end{tabular}

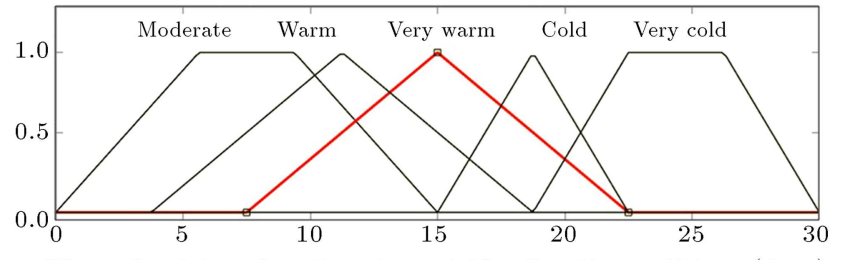

Time of painting functions in variable climatic conditions (days)

Figure 8. Fuzzy membership function of painting activity model in variable climatic conditions.

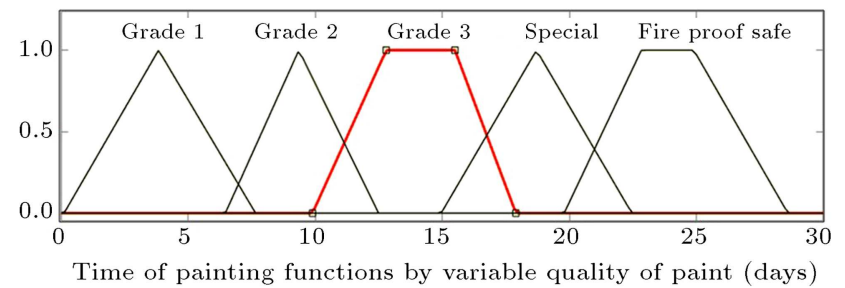

Figure 9. Fuzzy membership function of painting activity model with variable paint quality.

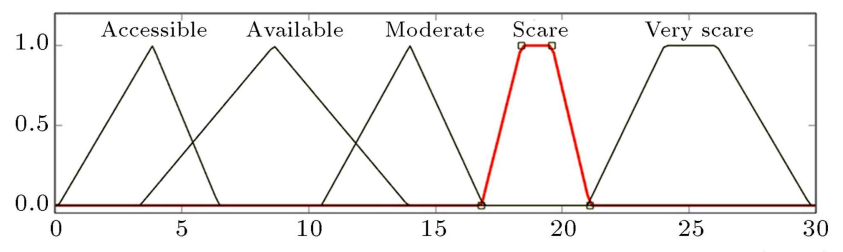

Time of painting functions by availability of skilled workers (days)

Figure 10. Fuzzy membership function of availability of skilled workers factor.

distributed among the mentioned team members. The second questionnaire was about estimating the time of each activity based on the experience of the professional team. After summing up the results of the first and second questionnaires, the obtained results were examined by a team composed of 9 expert project managers to determine content validity. In the next stages of the proposed model, time factors of membership functions of the activities were drawn according to the second questionnaire. In this research, fuzzy diagrams were of triangular and trapezoidal types. In the present example, Figures 8 to 11 indicate the fuzzy membership functions of painting activity factors. These diagrams were considered as the input in the MATLAB analysis.

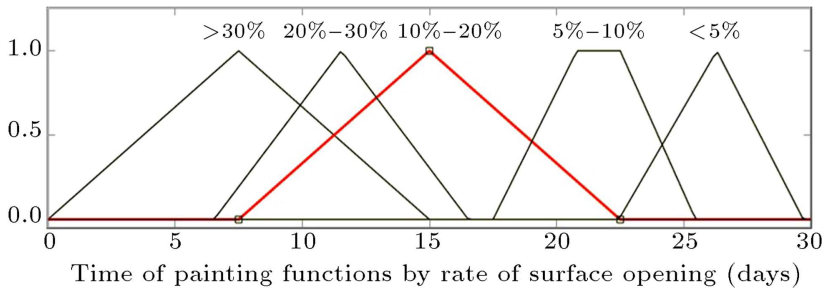

Figure 11. Fuzzy membership function of rate of surface opening factor.

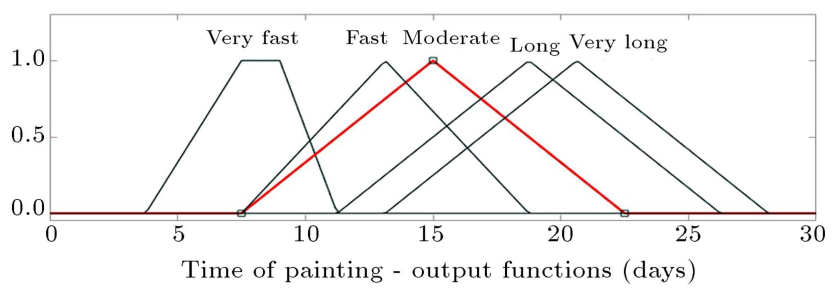

Figure 12. Time of painting activity-output functions.

Also, Figure 12 shows the output function of painting activity time. In the next stage, the results of the previous step as input were analyzed in Fuzzy Toolbox of MATLAB. This toolbox follows a rulebased system. Diagram of the analysis is presented in Figure 13. As it can be seen in this figure, inputs are processed by an intelligent rule-based system.

"IF ... Then ..." rules were set by the expert team in rule-based system. For example, for the 4 mentioned factors, 625 operating modes might occur. After analysis, the duration of activities under uncertainty and fuzzy approach could be achieved. Figure 14 shows the calculated painting time.

After calculating the time of all activities according to this model, project schedule was designed under possible uncertainty. Thus, in the next stage, in order to consider probable uncertainty, we needed to add project risks to the designed project schedule. The probable uncertainty in the model could be considered by two methods. The first method recognized the risks in terms of completed questionnaires and would handle other stages of project risk management based on the obtained results. In the second method, the results of previous studies through similar statistical data 
Table 5. Specifications of the selected papers by other contingency-mathematical approaches.

\section{Considered issues and problems}

Presenting an uncertain model for scheduling the logistics projects

GA approach to remanufacturing process scheduling

Heuristic procedures for reactive project scheduling

A genetic algorithm-based optimal resource-constrained scheduling simulation model

Applicability of optimal control theory to adaptive supply chain planning and scheduling

Genetic optimization of order scheduling with uncertainties

A two-stage-priority-rule-based algorithm for robust resource-constrained project scheduling

An event-driven approach with makespan/cost tradeoff analysis for project portfolio scheduling

Responding to schedule changes in build-to-order supply chains

Knowledge-based system for alternative design, cost estimating, and scheduling

A hybrid heuristic algorithm for flowshop inverse scheduling problem under a dynamic environment: cluster computing

A genetic algorithm-based optimizing approach for project time-cost trade-off with uncertain measure

A self-adjusting algorithm for driver scheduling

Model for evaluating networks under correlated uncertainty

Monte carlo simulation analysis at Lester B Pearson

international airport development project

Reliability buffering for construction projects. Journal of Construction Engineering and Management

Construction planning method using case-based reasoning (CONPLA-CBR). Journal of Computing in Civil Engineering

System of multiple ANNs for online project planning
Author(s), publishing year

KE et al., 2015 [180]

Zhang et al., 2015 [3]

Van de Vonder et al., 2007 [181]

Leu \& Hung, 2002 [182]

Ivanov et al., 2012 [183]

Guo et al., 2008 [184]

Chtourou \& Haouari, 2008 [185]

Kao et al., 2006 [186]

Krajewski et al., 2005 [187]

Mohamed \& Celik, 2002 [188]

Mou et al., 2017 [189]

Ke, 2014 [190]

Li, 2009 [191]

Wang \& Demsetz, 2000 [192]

Ersahin et al., 2003 [193]

Park M\& Peña-Mora, 2004 [194]

Ryu et al., 2007 [195]

Yousefi et al., 2008 [196] 
Table 5. Specifications of the selected papers by other contingency-mathematical approaches (continued).

\begin{tabular}{|c|c|}
\hline Considered issues and problems & Author(s), publishing year \\
\hline Time-cost optimization of nonserial repetitive construction projects & Ezeldin \& Soliman, 2009 [198] \\
\hline Time-scale network simulation by chronographic relations & Francis \& Miresco, 2011 [199] \\
\hline Simulating construction duration for multistory buildings & Nguyen et al., 2013 [200] \\
\hline $\begin{array}{l}\text { A mathematical structure for modeling uncertainty in } \\
\text { cost, schedule, and escalation factor in a portfolio of projects }\end{array}$ & Touran, 2014 [201] \\
\hline Scenario-based optimization for critical-chain project scheduling & Ma et al., 2015 [202] \\
\hline $\begin{array}{l}\text { Real-time construction schedule analysis of long-distance diversion } \\
\text { tunnels based predictions using a Markov process }\end{array}$ & Bi et al., 2014 [203] \\
\hline $\begin{array}{l}\text { Application of Weibull Analysis to evaluating and forecasting } \\
\text { of schedule performance in repetitive projects }\end{array}$ & Baqerin et al., 2015 [204] \\
\hline $\begin{array}{c}\text { Simulating uncertainties in construction projects with } \\
\text { chronographical scheduling logic }\end{array}$ & Francis, 2016 [205] \\
\hline $\begin{array}{l}\text { A genetic scheduling methodology for virtual cellular } \\
\text { manufacturing systems: an industrial application }\end{array}$ & Mak et al., 2005 [206] \\
\hline $\begin{array}{l}\text { The application of the ant colony optimization algorithm to } \\
\text { the construction site layout planning problem }\end{array}$ & Lam et al., 2007 [207] \\
\hline A framework for developing intelligent real time scheduling & McPherson \& White, 2006 [208] \\
\hline $\begin{array}{c}\text { Recommender system for software project planning, one } \\
\text { application of revised CBR algorithm }\end{array}$ & Yang \& Wang, 2009 [209] \\
\hline Development of a gray critical path for construction planning & Huang et al., 1997 [210] \\
\hline
\end{tabular}

Table 6. Questionnaire of fuzzy expert system for painting activity.

\section{Please determine the effect of each factor in the time of painting activity}

1- Climatic condition (very cold, cold, moderate. warm, Hot)

Very cold $\quad \square \quad$ Cold $\quad \square \quad$ Moderate $\quad \square \quad$ Warm $\quad \square \quad$ Hot

2- HSE criteria (classification of site in operational zones)
Out site
$\square \quad$ Guard fence
Muster point
$\square \quad$ Operational
H2S penetrate

3- Height of the surface (needing or not needing scaffolding)

Very short $\square \quad$ Short $\quad \square \quad$ Moderate $\quad \square \quad$ Tall $\quad \square \quad$ Very tall

4- Quality of paint (Grade 1, Grade 2, Grade 3, Special, Fire-proof safe)
Grade 3
Grade 2
Grade 1
Special
FP safe

5 - Availability of skilled workers

Very scarce $\quad \square \quad$ Scarce $\quad \square \quad$ Moderate $\square \quad$ Available $\square \quad$ Accessible

6- Rate of surface opening (30\%, 20\%-30\%, 10\%-20\%, $55 \%)$
$>30 \%$
$20 \%-30 \%$
$10 \%-20 \%$
5\%-10\%
$<5 \%$

7- Type of paint material (plastic color T1,.., oil color-T2)

Plastic color $1 \quad \square \quad$ Plastic color $2 \quad \square \quad$ Plastic color $3 \quad \square \quad$ Oil color-T1 $\square \quad$ Oil color-T2 
Table 7. First reliability analysis of questionnaire (Cronbach's alpha $=0.538$ ).

\begin{tabular}{ccccc}
\hline & $\begin{array}{c}\text { Scale mean if item } \\
\text { is deleted }\end{array}$ & $\begin{array}{c}\text { Scale variance if } \\
\text { item is deleted }\end{array}$ & $\begin{array}{c}\text { Corrected item-total } \\
\text { correlation }\end{array}$ & $\begin{array}{c}\text { Cronbach's alpha if } \\
\text { item is deleted }\end{array}$ \\
\hline S1601 & 11.73 & 3.857 & 0.709 & 0.287 \\
S1602 & 11.70 & 6.562 & -0.161 & 0.647 \\
S1603 & 11.33 & 5.816 & -0.006 & 0.620 \\
S1604 & 11.73 & 3.857 & 0.709 & 0.287 \\
S1605 & 11.73 & 3.857 & 0.709 & 0.287 \\
S1606 & 10.87 & 5.292 & 0.403 & 0.467 \\
S1607 & 11.70 & 6.562 & -0.161 & 0.647 \\
\hline
\end{tabular}

Table 8. Second reliability analysis of questionnaire (Cronbach's alpha $=0.939$ ).

\begin{tabular}{ccccc}
\hline & $\begin{array}{c}\text { Scale mean if } \\
\text { item is deleted }\end{array}$ & $\begin{array}{c}\text { Scale variance if } \\
\text { item is deleted }\end{array}$ & $\begin{array}{c}\text { Corrected item-total } \\
\text { correlation }\end{array}$ & $\begin{array}{c}\text { Cronbach's alpha if } \\
\text { item is deleted }\end{array}$ \\
\hline S1601 & 6.07 & 3.237 & 0.973 & 0.878 \\
S1604 & 6.07 & 3.237 & 0.973 & 0.878 \\
S1605 & 6.07 & 3.237 & 0.973 & 0.878 \\
S1606 & 5.20 & 4.924 & 0.543 & 1.000 \\
\hline
\end{tabular}

Table 9. Correlation survey by Pearson coefficient.

\begin{tabular}{llllll}
\hline & & S1601 & S1604 & S1605 & S1606 \\
\hline S1601 & Pearson correlation & 1 & $0.843^{* *}$ & $0.937^{* *}$ & $0.742^{* *}$ \\
& Sig. (2-tailed) & & 0.000 & 0.000 & 0.002 \\
& N & 30 & 30 & 30 & 30 \\
S1604 & Pearson correlation & $0.843^{* *}$ & 1 & $0.711^{* *}$ & $0.821^{* *}$ \\
& Sig. (2-tailed) & 0.000 & & 0.000 & 0.002 \\
& N & 30 & 30 & 30 & 30 \\
S1605 & Pearson correlation & $0.937^{* *}$ & $0.711^{* *}$ & 1 & $0.953^{* *}$ \\
& Sig. (2-tailed) & 0.000 & 0.000 & & 0.002 \\
& N & 30 & 30 & 30 & 30 \\
& & & & & \\
S1606 & Pearson correlation & $0.742^{* *}$ & $0.821^{* *}$ & $0.953^{* *}$ & 1 \\
& Sig. (2-tailed) & .002 & 0.002 & 0.002 & \\
& N & 30 & 30 & 30 & 30 \\
\hline
\end{tabular}

** Correlation is significant at the 0.01 level (2-tailed).

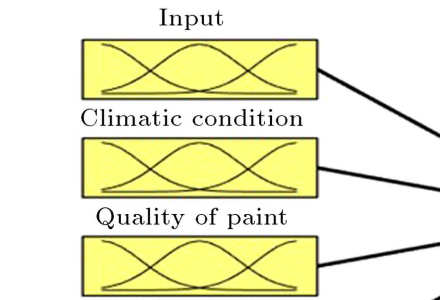

Availability of skilled worker

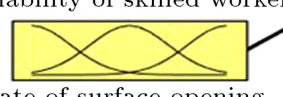

Painting time (Mamdani)

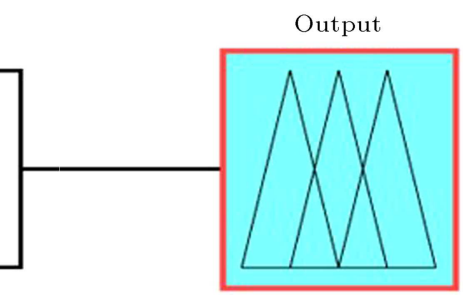

Painting time (regarding uncertainty)

Figure 13. Diagram of the analysis of the proposed model for painting activity. 


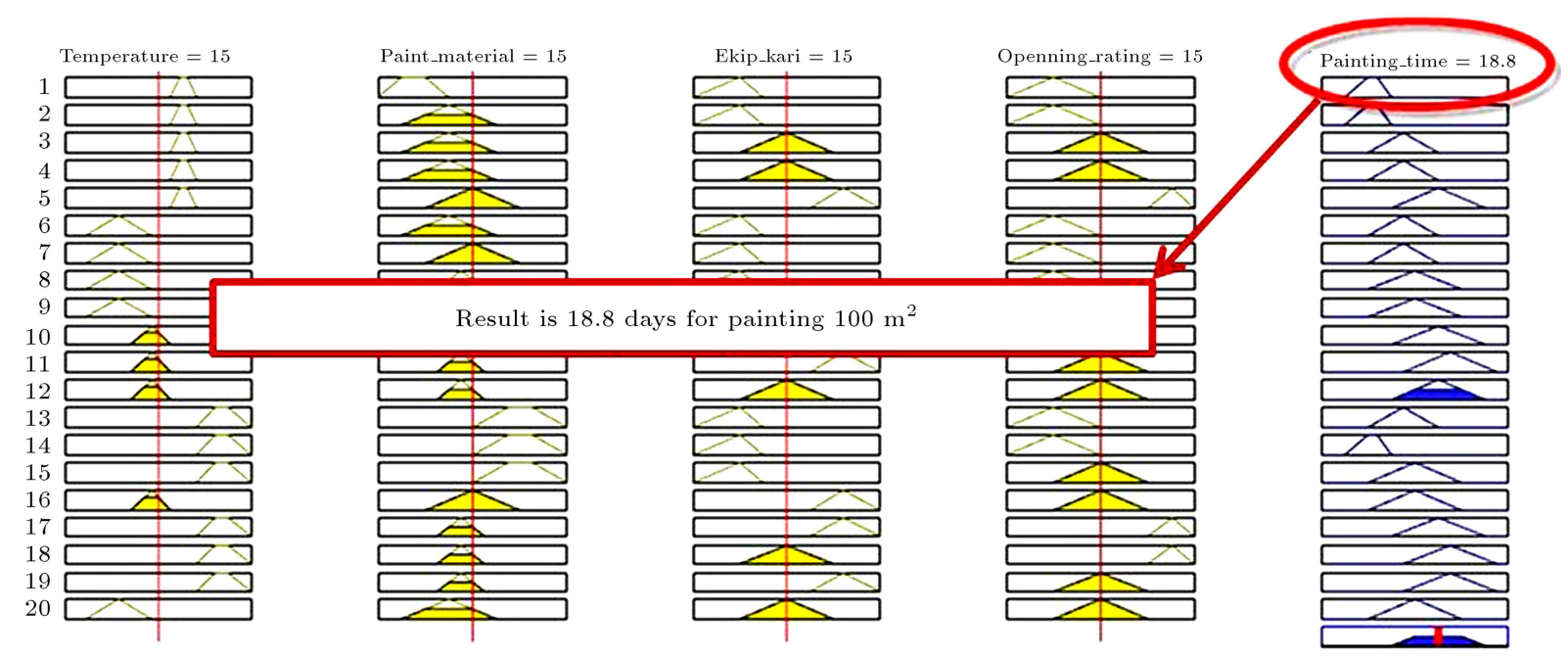

Figure 14. Painting time calculated by the output of the fuzzy approach in MATLAB software.

Table 10. The main historical researchers of risk management in Iranian gas refineries from 2010 to 2017.

\begin{tabular}{|c|c|}
\hline Researcher(s)/year & Approach of research \\
\hline Rudloff and Schultz, 2016 [211] & They reviewed project risk in the oil and gas industry. \\
\hline Ghasemi et al., 2015 [212] & $\begin{array}{l}\text { They presented a new method to scrutinize } \\
\text { the insurable risk in Iranian gas refineries by FMEA. }\end{array}$ \\
\hline Najafi et al., 2015 [213] & They reviewed risk quantification in complex and fast projects. \\
\hline Doosti et al., 2014 [214] & They reviewed the risk management in the construction of gas refineries. \\
\hline Ardeshir et al., 2014 [215] & $\begin{array}{l}\text { They reviewed safety assessment in refinery and } \\
\text { other construction projects based on analytic hierarchy process. }\end{array}$ \\
\hline Bordbar et al., 2013 [216] & $\begin{array}{l}\text { They reviewed the identification and allocation of } \\
\text { risks in construction projects of Sarkhoon \& Gheshm gas refinery. }\end{array}$ \\
\hline Amanatyazdi \& Moharramnejad, 2013 [217] & They reviewed risk management in Iranian oil and gas companies. \\
\hline Hamzei \& Alamtabriz, 2012 [218] & $\begin{array}{l}\text { They proposed a new hybrid method for project risk assessment in } \\
\text { construction projects. Also, they reviewed the risks in refinery projects. }\end{array}$ \\
\hline Attarzadeh et al., 2011 [219] & They reviewed the risk management of Asaluyeh desalination projects. \\
\hline Soltani et al., 2011 [220] & They reviewed the risks of projects in Shiraz refinery by FMEA method. \\
\hline Jalaee \& Mahdaviparsa, 2010 [221] & $\begin{array}{l}\text { They studied risk management in Iranian construction projects } \\
\text { such as gas refineries as a survey study. }\end{array}$ \\
\hline
\end{tabular}

derived from similar projects were utilized. Since the application of risk management in gas refineries goes back to many years ago, the second method is a highpriority one. Thus, this study attempts to review the literature on risk management in construction projects of Iranian gas refineries, which have been completed from 2010 to 2017 (Table 10). These studies were classified as a database for construction project risks in gas refineries (Table 11). In the following stages, the expert team allocated the selected risks to each project as probable activities.

Also, there were two procedures for allocating 
Table 11. Sample database of construction project risk index (RPN) in gas refineries.

\begin{tabular}{cccccc}
\hline No & Risk description & RPN & No & Risk description & RPN \\
\hline 1 & Damage caused by animals/insects & 96 & 11 & Toxicity of chemical spill & 288 \\
2 & Work injury due to cutting & 105 & 12 & Explosion & 373 \\
3 & Clash with underground pipes & 120 & 13 & Burns from an electric shock & 383 \\
4 & Fire-damage to persons & 120 & 14 & Fire-refinery equipment damage & 390 \\
5 & Welding-damage to the eyes & 120 & 15 & Damage due to excavation & 392 \\
6 & Fluctuations in the price of cement & 150 & 16 & Work injury due to falling objects & 424 \\
7 & Lack of necessary infrastructure & 210 & 17 & Falling from openings & 524 \\
8 & Price eccentricity of contractors & 216 & 18 & Falling from structure & 565 \\
9 & Fluctuations in steel prices and rebar & 252 & 19 & Falling from scaffolding & 570 \\
10 & Political and economic sanctions & 280 & 20 & Falling from crane & 600 \\
\hline
\end{tabular}

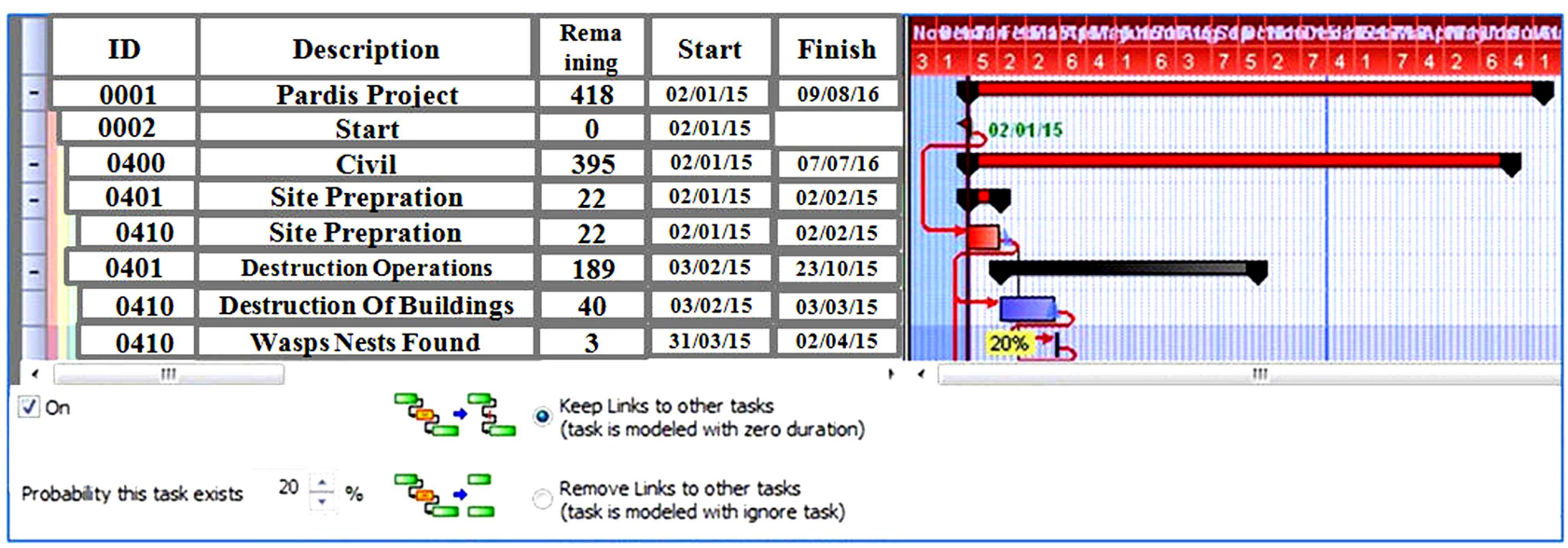

Figure 15. Sample of probable activity in project scheduling - wasps nests found.

risks to project activities in the proposed model of the present study. The first procedure was allocating the risks to each activity as a probable activity and the second one was allocating probable branches to the intended activities. For example, in a destruction operations activity, the risk of "Wasps nests found" with a probability of $5 \%$ was allocated to risk management in project scheduling (Figure 15). Also, risks could be allocated to activities as probable branches. For example, in "Excavation" activity, three probable branches were considered. These branches were: (1) "Normal condition" with the probability of $70 \%$; (2) "Finding ground water in the site area" with the probability of 20\%; (3) "Finding antique objects underground" with the probability of $5 \%$ (Figure 16).

In the final stage of the proposed model, project schedule was designed based on managing both types of uncertainties. Then, the provided schedule was analyzed on the basis of Monte Carlo model. This analysis was done by the Risk Analysis software. Primavera Risk Analysis is a full lifecycle risk analytics solution that provides a comprehensive means for determining confidence levels for project success with quick and easy techniques for determining contingency and risk response plans. If the project schedule has a confidence level of 95 percent, it will be accepted; otherwise, it should be rechecked to undergo possible modifications.

\section{Results of implementation of the proposed model}

The proposed model was implemented in a gas refinery in the north-east of Iran. This gas refinery provides cooking and industrial gas for 5 provinces in the north and east of Iran, including Khorasan area (three provinces), Semnan, and some parts of Golestan. The period of study was between 2014 and 2016, and the sampling of this study was composed of 30 projects based on Cochran formula. Table 12 presents the titles of the projects done in research studies in correspondence with project estimation accuracies in ascending order. 


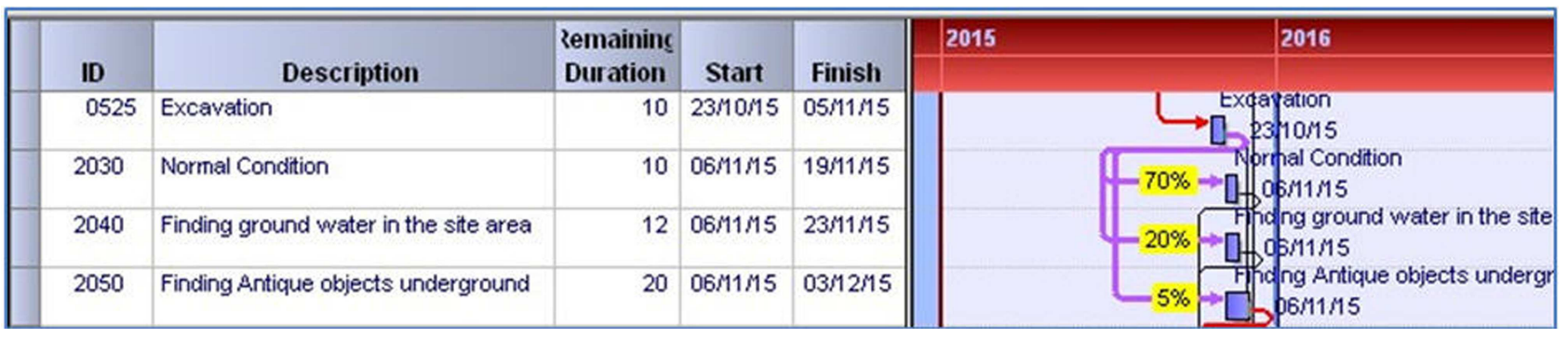

Figure 16. Sample of probable activity in project scheduling-excavation.

Table 12. The titles of projects that are used in the research studies.

\begin{tabular}{clcl}
\hline Project ID & \multicolumn{1}{c}{ Title of project } & Project ID & \multicolumn{1}{c}{ Title of project } \\
\hline P001 & Construction of sculpture unit road & P016 & Construction of housing center \\
P002 & Construction of Pardis staff pension & P017 & Movement of Gonbazli sole \\
P003 & Construction of warehouse building & P018 & Construction of oil loading pavement \\
P004 & Degassing of granulation unit & P019 & Performing of Pardis power \& data line \\
P005 & Construction of senior operator room & P020 & Construction of loading HC-condensate area \\
P006 & Performing of O.W.S supports & P021 & Performing of general civil maintenance \\
P007 & Construction of gas station & P022 & Optimization of Shahid Mohajer pool \\
P008 & Construction of HSE energy channel & P023 & Construction of transportation sole \\
P009 & Construction of Torshizi sewage & P024 & Construction of contractor building \\
P010 & Performing of refinery F\&G system & P025 & Restaurant's cold and mechanical rooms \\
P011 & Installation of the 7th boiler of refinery & P026 & Construction of TPL fencing \\
P012 & Extending of central restaurant & P027 & Performing of Pardis waterline \\
P013 & Construction of sculpture platform & P028 & P.F wall in Torshizi residential \\
P014 & Construction of oily water separator & P029 & Performing of Pardis gas line \\
P015 & Performing of Pardis complex sewage line & P030 & Construction of CMF pipe line \\
\hline
\end{tabular}

For implementing the proposed model, at first, two professional questionnaires were distributed among a professional team, which was selected by the staff of 70 contractors, consultants, and client companies. The first questionnaire was designed to identify effective factors on doing project activities. Then, obtained linguistic variables were translated into mathematical measures. In the following, obtained information was processed by MATLAB and fuzzy times were dedicated to project activities. In the second phase, risks were added to project as probable activities. Finally, the integrated time of projects activities was analyzed by Monte Carlo method; the outputs showed that the accuracy of project time calculation was improved by about 8 to 24 percent. Figure 17 indicates the improvement of the mentioned project time estimation.

\section{Conclusions}

In this paper, the literature on uncertainty management in construction projects was reviewed comprehensively. At first, 9236 papers from 6 main online databases were preliminarily reviewed and 242 papers were selected for precise review. According to the analysis of the mentioned papers, the following conclusions were derived:

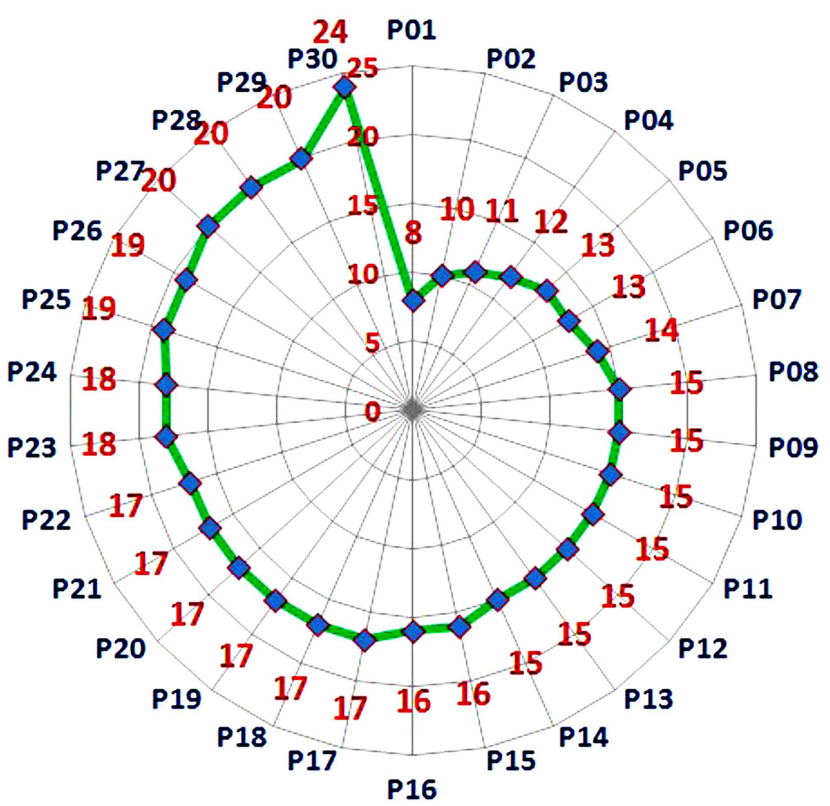

Figure 17. The rate of improvement in project time estimation by the proposed model.

1. About 29 percent of the last studies considered the possible theory to manage uncertainties in construction project scheduling. They applied fuzzy technique in this field. Thus, the fuzzy technique 
was the most applicable method to manage possible uncertainties in construction project scheduling;

2. About 71 percent of the last studies considered the probable theory to manage uncertainties in construction project scheduling and about 80 percent of probable approach (equal to 57 percent of the last studies) belonged to the application of risk management in this field. Other contingency approaches were genetic algorithm, neural network, linear programming, Markov chain, Monte Carlo Simulation, and other mathematical methods and heuristic algorithms. Thus, Risk Management was the most applicable method to manage probable uncertainties in construction project scheduling;

3. Finally, a precise model was proposed to provide comprehensive project time estimation. The proposed model integrated the risk management and fuzzy expert systems in order to manage both modes of time uncertainty in the construction projects of Iranian gas refineries;

4. The result of the implementation of the proposed model showed that the accuracy of project time estimation increased by about 8 to 24 percent. According to successful results of this research, it is suggested that the proposed model could be generalized to projects of other industries.

\section{References}

1. Jiang, S.L., Liu, M., Lin, J.H., and Zhong, H.X. "A prediction-based online soft scheduling algorithm for the real-world steelmaking-continuous casting production", Knowledge-Based Systems, 111, pp. 159$172(2016)$.

2. Al-Dhaheri, N., Jebali, A., and Diabat, A. "A simulation-based genetic algorithm approach for the quay crane scheduling under uncertainty", Simulation Modeling Practice and Theory, 66, pp. 122-138 (2016). DOI: 10.1016/j.simpat.2016.01.009

3. Zhang, R., Ong., S.K., and Nee, A.Y. "A simulationbased genetic algorithm approaches for remanufacturing process planning and scheduling", Applied Soft Computing, 37, pp. 521-532 (2015).

4. Józefczyk, J. and Thomas, W. "Robust algorithm for scheduling of manufacturing tasks with interval execution times", IFAC Proceedings Volumes, 40(3), pp. $75-80$ (2007).

5. Kokkaew, N. and Chiara, N. "Modeling completion risk using stochastic critical path envelope method: a BOT highway project application", Construction Management and Economics, 28(12), pp. 1239-1254 (2010). DOI: 10.1080/01446193.2010.521755

6. Li, C., Liu, F., Cao, H., and Wang, Q. "A stochastic dynamic programming based model for uncertain production planning of re-manufacturing system", Inter- national Journal of Production Research, 47(13), pp. 3657-3668 (2009). DOI:10.1080/00207540701837029

7. Tran, D. and Molenaar, K. "Critical risk factors in project delivery method selection for highway projects", In Construction Research Congress 2012: Construction Challenges in a Flat World, pp. 331-340 (2012). DOI:10.1061/9780784412329.034.

8. Yagi, J. and Arai, E. "Matsumoto S. Action-based union of the temporal opposites and elastic activity network in scheduling", Automation in Construction, 15(5), pp. 604-615 (2006).

9. Taghaddos, H., Hermann, U., AbouRizk, S., and Mohamed, Y. "Simulation-based multiage approach for scheduling modular construction", Journal of Computing in Civil Engineering, 28(2), pp. 263-274 (2012). DOI:10.1061/(ASCE)CP.1943-5487.0000262.

10. Özdamar, L. and Alanya, E. "Uncertainty modeling in software development projects (with case study)", Annals of Operations Research, 102(1), pp. 157-178 (2001).

11. Li, H., Tu, H., and Hensher, D.A. "Integrating the mean-variance and scheduling approaches to allow for schedule delay and trip time variability under uncertainty", Transportation Research, Part A: Policy and Practice, 89, pp. 151-163 (2016). DOI:10.1016/j.tra.2016.05.014

12. Ok, S.Y., Lee, S.Y., and Park, W. "Robust multiobjective maintenance planning of deteriorating bridges against uncertainty in performance model", Advances in Engineering Software, 65, pp. 32-42 (2013). DOI: 10.1016/j.advengsoft.2013.05.009

13. Arshadi Khamseh, A. and Mahmoodi, M. "A new fuzzy TOPSIS-TODIM hybrid method for green supplier selection using fuzzy time function", Advances in Fuzzy Systems, 2014, pp. 1-13 (2014). DOI: $10.1155 / 2014 / 841405$

14. Eğrioğlu, E. "A new time-invariant fuzzy time series forecasting method based on genetic algorithm", $A d$ vances in Fuzzy Systems, 2012, Article ID 785709 (2012). .

15. Ock, J.H. and Han, S.H. "Measuring risk-associated activity's duration: A fuzzy set theory application", KSCE Journal of Civil Engineering, 14(5), pp. 663671 (2010).

16. Zhang, J., Qin, W., Wu, L.H., and Zhai, W.B. "Fuzzy neural network-based rescheduling decision mechanism for semiconductor manufacturing", Computers in Industry, 65(8), pp. 1115-1125 (2014). DOI: 10.1016/j.compind.2014.06.002

17. Zha, H. and Zhang, L. "Fuzzy flexible resource constrained project scheduling based on genetic algorithm", Transactions of Tianjin University, 20(6), pp. 469-674 (2014).

18. Leu, S.S., Chen, A.T., and Yang, C.H. "A GAbased fuzzy optimal model for construction time-cost trade-off", International Journal of Project Management, 19(1), pp. 47-58 (2001). DOI: 10.1016/S02637863(99)00035-6 
19. Muhuri, P.K. and Shukla, A.K. "Semi-elliptic membership function: Representation, generation, operations, defuzzification, ranking and its application to the real-time task scheduling problem", Engineering Applications of Artificial Intelligence, 1, pp. 71-82 (2017). DOI: 10.1016/j.engappai.2016.12.020

20. Dubois, D., Fargier, H., and Fortemps, P. "Fuzzy scheduling: Modelling flexible constraints vs. coping with incomplete knowledge", European Journal of Operational Research, 147(2), pp. 231-52 (2003). DOI: $10.1016 / \mathrm{S} 0377-2217(02) 00558-1$

21. Geyik, F. and Elibal, K. "A linguistic approach to non-identical parallel processor scheduling with fuzzy processing times", Applied Soft Computing, 55, pp. 63-71 (2017). DOI: 10.1016/j.asoc.2016.12.029

22. Jayagowri, P. and Ramani, G.G. "Using trapezoidal intuitionist fuzzy number to find optimized path in a network", Advances in Fuzzy Systems, 2014, pp. 1-6, Article ID 183607 (2014). DOI: 10.1155/2014/183607.

23. Benítez-Pérez, H., Benítez-Pérez, A., Ortega-Arjona, J., and Esquivel-Flores, O. "Fuzzy networked control systems design considering scheduling restrictions", Advances in Fuzzy Systems, 2012, pp. 54-59 (2012).

24. Eğrioğlu, E. "A new time-invariant fuzzy time series forecasting method based on genetic algorithm", $A d$ vances in Fuzzy Systems, 2012, Article ID 785709 (2012). DOI: $10.1155 / 2012 / 785709$.

25. Afshar, A. and Fathi, H. "Fuzzy multi-objective optimization of finance-based scheduling for construction projects with uncertainties in cost", Engineering Optimization, 41(11), pp. 1063-80 (2009).

26. Lam, K.C., So, A.T., Hu, T., Ng, T., Yuen, R.K., Lo, S.M., Cheung, S.O., and Yang H. "An integration of the fuzzy reasoning technique and the fuzzy optimization method in construction project management decision-making", Construction Management and Economics, 19(1), pp. 63-76 (2001).

27. Shanker, R. and Vrat, P. "Some design issues in cellular manufacturing using the fuzzy programming approach", International Journal of Production Research, 37(11), pp. 2545-63 (1999).

28. Ayyub, B.M. and Haldar, A. "Project scheduling using fuzzy set concepts", Journal of Construction Engineering and Management, 110(2), pp. 189-204 (1984). DOI: 10.1061/(ASCE)07339364(1984)110:2(189).

29. Leu, S.S., Chen, A.T., and Yang, C.H. "Fuzzy optimal model for resource-constrained construction scheduling", Journal of Computing in Civil Engineering, 13(3), pp. 207-16 (1999).

30. Bonnal, P., Gourc, D., and Lacoste, G. "Where do we stand with fuzzy project scheduling?", Journal of Construction Engineering and Management, 130(1), pp. 114-23 (2004).

31. Oliveros, A.V. and Fayek, A.R. "Fuzzy logic approach for activity delay analysis and schedule updating", Journal of Construction Engineering and Management, 131(1), pp. 42-51 (2005).
32. Maravas, A. and Pantouvakis, J.P. "Fuzzy repetitive scheduling method for projects with repeating activities", Journal of Construction Engineering and Management, 137(7), pp. 561-4 (2010). DOI: 10.1061/(ASCE)CO.1943-7862.0000319

33. Maravas, A. and Pantouvakis, J.P. "A process for the estimation of the duration of activities in fuzzy project scheduling", Vulnerability, Uncertainty, and Risk: Analysis, Modeling, and Management, 8 pp. 62-69 (2011). DOI: 10.1061/41170(400)8

34. Xiong, G. and Wang, H. "Emergency scheduling model of multi-objective-to-resource under uncertain requirements", In ICLEM 2014: System Planning, Supply Chain Management, and Safety, pp. 440-446 (2014). DOI: 10.1061/9780784413753.067

35. Guo, P., Wang, X., Zhu, H., and Li, M. "Inexact fuzzy chance-constrained nonlinear programming approach for crop water allocation under precipitation variation and sustainable development", Journal of Water Resources Planning and Management, 140(9), pp. 58-72 (2014).

DOI: 10.1061/(ASCE)WR.1943-5452.0000385.

36. Smith, G.R. and Hancher, D.E. "Estimating precipitation impacts for scheduling", Journal of Construction Engineering and Management, 115(4), pp. 552-566 (1989). DOI: 10.1061/(ASCE)07339364(1989)115:4(552)

37. Chang, T.C., Ibbs, C.W., and Crandall, K.C. "Network resource allocation with support of a fuzzy expert system", Journal of Construction Engineering and Management, 116(2), pp. 239-260 (1990). DOI: 10.1061/(ASCE)0733-9364(1990)116:2(239).

38. Kikuchi, S. and Donnelly, R.A. "Scheduling demandresponsive transportation vehicles using fuzzy-set theory", Journal of Transportation Engineering, 118(3), pp. 391-409 (1992).

39. Crump, E.L., Jacobs, T.L., and Vesilind, P.A. "Fuzzy-set approach for optimizing sludge application land selection", Journal of Urban Planning and Development, 119(2), pp. 53-71 (1993).

40. Kumar, V.S., Natarajan, P., and Hanna, A.S. "Application of fuzzy linear programming in building engineering", Computing in Civil and Building Engineering, 1, pp. 1347-1354 (2000).

41. Li, J., Moselhi, O., and Alkass, S. "Forecasting project status by using fuzzy logic", Journal of Construction Engineering and Management, 132(11), pp. 1193-202 (2006). DOI: 10.1061/(ASCE)07339364(2006)132:11(1193).

42. Castro-Lacouture, D., Süer, G.A., Gonzalez-Joaqui, J., and Yates, J.K. "Construction project scheduling with time, cost, and material restrictions using fuzzy mathematical models and critical path method", Journal of Construction Engineering and Management, 135(10), pp. 1096-1104 (2009).

43. Abido, M.A. and Elazouni, A.M. "Multiobjective evolutionary finance-based scheduling: Entire projects' portfolio", Journal of Computing in 
Civil Engineering, 25(1), pp. 85-97 (2010). DOI: 10.1061/(ASCE)CP.1943-5487.0000070

44. Al-Humaidi, H.M. and Tan, F.H. "New approach to model material-related problems contributing to project delays using rotational fuzzy set", Journal of Performance of Constructed Facilities, 26(3), pp. 279-86 (2011). DOI: 10.1061/(ASCE)CF.19435509.0000220 .

45. Chrysafis, K.A. and Papadopoulos, B.K. "Possibility moments for the task duration in fuzzy PERT", Journal of Management in Engineering, 31(5) (Sep. 2015).

46. Sadeghi, N., Fayek, A.R., and Gerami Seresht, $\mathrm{N}$. "A fuzzy discrete event simulation framework for construction applications", Improving the Simulation Time Advancement. Journal of Construction Engineering and Management, 142(12), pp. 116-122 (2016). DOI: 10.1061/(ASCE)CO.19437862.0001195 .

47. Maravas, A. and Pantouvakis, J.P. "A process for the estimation of the duration of activities in fuzzy project scheduling", Vulnerability, Uncertainty, and Risk: Analysis, Modeling, and Management, 2011, pp. 62-69 (2011). DOI: 10.1061/41170(400)8.

48. Anoop, M.B. and Balaji Rao, K. "Application of fuzzy sets for remaining life assessment of corrosion affected reinforced concrete bridge girders", Journal of Performance of Constructed Facilities, 21(2), pp. 166-171 (2007). DOI: 10.1061/(ASCE)0887$3828(2007) 21: 2(166)$

49. Oliveros, A.V. and Fayek, A.R. "Fuzzy logic approach for activity delay analysis and schedule updating", Journal of Construction Engineering and Management, 131(1), pp. 42-51 (2005).

50. Leu, S.S. and Hung, T.H. "A genetic algorithmbased optimal resource-constrained scheduling simulation model", Construction Management \& Economics, 20(2), pp. 131-141 (2002). DOI: 10.1061/(ASCE)0887-3801(1999)13:3(207).

51. Marmier, F., Varnier, C., and Zerhouni, N. "Robustness measure for fuzzy maintenance activities schedule", IFAC Proceedings Volumes, 40(18), pp. 8590 (2007).

52. Mousavi, S.M., Vahdani, B., Tavakkoli-Moghaddam, R., and Hashemi, H. "Location of cross-docking centers and vehicle routing scheduling under uncertainty: A fuzzy possibilistic-stochastic programming model", Applied Mathematical Modelling, 38(7), pp. 22492264 (2014).

53. Ke, H. and Ma, J. "Modeling project time-cost trade-off in fuzzy random environment", Applied Soft Computing, 19, pp. 80-5 (2014).

DOI: $10.1016 /$ j.asoc.2014.01.040.

54. Dixit, V., Srivastava, R.K., and Chaudhuri, A. "Procurement scheduling for complex projects with fuzzy activity durations and lead times", Computers \& Industrial Engineering, 76, pp. 401-14 (2014).
55. Masmoudi, M. and Hait, A. "Project scheduling under uncertainty using fuzzy modeling and solving techniques", Engineering Applications of Artificial Intelligence, 26(1), pp. 135-49 (2013).

56. Isaai, M.T., Kanani, A., Tootoonchi, M., and Afzali, H.R. "Intelligent timetable evaluation using fuzzy AHP", Expert Systems with Applications, 38(4), pp. 3718-3723 (2011).

57. Muhuri, P.K. and Shukla, K.K. "Real-time scheduling of periodic tasks with processing times and deadlines as parametric fuzzy numbers", Applied Soft Computing, 9(3), pp. 936-946 (2009).

58. Torabi, S.A., Ebadian, M., and Tanha, R. "Fuzzy hierarchical production planning (with a case study)", Fuzzy Sets and Systems, 161(11), pp. 1511-1529 (2010). DOI: 10.1016/j.fss.2009.11.006.

59. Mula, J., Poler, R., and Garcia, J.P. "MRP with flexible constraints: A fuzzy mathematical programming approach", Fuzzy Sets and Systems, 157(1), pp. 74-97 (2006).

60. Mula, J., Poler, R., and Garcia-Sabater, J.P. "Material requirement planning with fuzzy constraints and fuzzy coefficients", Fuzzy Sets and Systems, 158(7), pp. 783-793 (2007).

61. Long, L.D. and Ohsato, A. "Fuzzy critical chain method for project scheduling under resource constraints and uncertainty", International Journal of Project Management, 26(6), pp. 688-698 (2008).

62. Hapke, M., Jaszkiewicz, A., and Slowinski, R. "Fuzzy project scheduling system for software development", Fuzzy Sets and Systems, 67(1), pp. 101-17 (1994). DOI: $10.1016 / 0165-0114(94) 90211-9$

63. Wang, J. "A fuzzy project scheduling approach to minimize schedule risk for product development", Fuzzy Sets and Systems, 127(2), pp. 99-116 (2002). DOI: 10.1016/S0165-0114(01)00146-4.

64. Wang, C., Jiang, C., and Liu, X. "Fuzzy logic-based secures and fault tolerant job scheduling in grid", Tsinghua Science \& Technology, 12, pp. 45-50 (2007). DOI: 10.1016/S1007-0214(07)70082-2

65. Muhuri, P.K. and Shukla, K.K. "Real-time task scheduling with fuzzy uncertainty in processing times and deadlines", Applied Soft Computing, 8(1), pp. 1-3 (2008).

66. Atli, O. and Kahraman, C. "Fuzzy resourceconstrained project scheduling using taboo search algorithm", International Journal of Intelligent Systems, 27(10), pp. 873-907 (2012).

67. Ponz-Tienda, J.L., Pellicer, E., Benlloch-Marco, J., and Andrés-Romano, C. "The fuzzy project scheduling problem with minimal generalized precedence relations", Computer-Aided Civil and Infrastructure Engineering, 30(11), pp. 872-91 (2015). DOI: $10.1111 /$ mice. 12166 .

68. Bellagamba, L. "4 estimating risk adjusted cost or schedule using fuzzy logic", INCOSE International Symposium, 9(1), pp. 241-246 (1999). DOI: 10.1002/j.2334-5837.1999.tb00166.x 
69. Sadeghi, N., Fayek, A.R., and Pedrycz, W. "Fuzzy Monte Carlo simulation and risk assessment in construction", Computer-Aided Civil and Infrastructure Engineering, 25(4), pp. 238-52 (2010).

70. Guo, S.J. "Computer-aided project duration forecasting subjected to the impact of rain", Computer-Aided Civil and Infrastructure Engineering, 15(1), pp. 67-74 (2000).

71. Behnamian, J. "Survey on fuzzy shop scheduling", Fuzzy Optimization and Decision Making, 15(3), pp. 331-366 (2016).

72. Liu, Z., Qu, W., Liu, W., Li, Z., and Xu, Y. "Resource preprocessing and optimal task scheduling in cloud computing environments", Concurrency and Computation: Practice and Experience, 27(13), pp. 3461-82 (2015). DOI: $10.1002 /$ cpe.3204.

73. Itoh, T. and Ishii, H. "Fuzzy due-date scheduling problem with fuzzy processing time", International Transactions in Operational Research, 6(6), pp. 63947 (1999).

74. Behnamian, J. "Survey on fuzzy shop scheduling", Fuzzy Optimization and Decision Making, 15(3), pp. 331-66 (2016).

75. Vidalakis, C., Tookey, J.E., and Sommerville, J. "Demand uncertainty in construction supply chains: a discrete event simulation study", Journal of the Operational Research Society, 64(8), pp. 1194-204 (2013).

76. Ghazanfari, M., Yousefli, A., Jabal Ameli, M.S., and Bozorgi-Amiri, A. "A new approach to solve timecost trade-off problem with fuzzy decision variables", The International Journal of Advanced Manufacturing Technology, 42(3), pp. 408-414 (2009).

77. Bidot, J., Vidal, T., Laborie, P., and Beck, J.C. "A theoretic and practical framework for scheduling in a stochastic environment", Journal of Scheduling, 12(3), pp. 315-44 (2009).

78. Wang, J.R. "A fuzzy set approach to activity scheduling for product development", Journal of the Operational Research Society, 50, pp. 1217-1228 (1999).

79. Huang, W., Ding, L., Wen, B., and Cao, B. "Project scheduling problem for software development with random fuzzy activity duration times", Advances in Neural Networks-ISNN, 2009, pp. 60-69 (2009).

80. Ding, C. and Zhu, Y. "Two empirical uncertain models for project scheduling problem", Journal of the Operational Research Society, 66(9), pp. 1471-80 (2015).

81. Fortin, J., Zieliński, P., Dubois, D., and Fargier, H. "Criticality analysis of activity networks under interval uncertainty", Journal of Scheduling, 13(6), pp. 609-27 (2010).

82. Keller, B. and Bayraksan, G. "Scheduling jobs sharing multiple resources under uncertainty: A stochastic programming approach", Iie Transactions, 42(1), pp. 16-30 (2009).
83. Fernandez, A.A., Armacost, R.L., and Pet-Edwards, J.J. "Understanding simulation solutions to resource constrained project scheduling problems with stochastic task durations", Engineering Management Journal, 10(4), pp. 5-13 (1998).

84. Reed, A.H. and Knight, L.V. "Project duration and risk factors on virtual projects", Journal of Computer Information Systems, 54(1), pp. 75-83 (2013).

85. Küchler, C. and Vigerske, S. "Numerical evaluation of approximation methods in stochastic programming", Optimization, 59(3), pp. 401-15 (2010).

86. Kang, L.S., Moon, H.S, Kim, H.S., Choi, G.Y., and Kim, C.H. "Development of 5D CAD system for visualizing risk degree and progress schedule for construction project", Computing in Civil Engineering, pp. 690-687 (2011). DOI: 10.1061/41182(416)85

87. Poshdar, M., González, V.A., Raftery, G.M., Orozco, F., Romeo, J.S., and Forcael, E. "A probabilisticbased method to determine optimum size of project buffer in construction schedules", Journal of Construction Engineering and Management, 142(10), pp. 68-74 (Oct. 2016). DOI: 10.1061/(ASCE)CO.1943-7862.0001158

88. Shahtaheri, M., Haas, C.T., and Salimi, T. "A stochastic simulation approach for the integration of risk and uncertainty into megaproject cost and schedule estimates", Construction Research Congress, pp. 607-615 (2016). DOI: 10.1061/(ASCE)CO.19437862.0001158 .

89. De Marco, A., Rafele, C., and Thaheem, M.J. "Dynamic management of risk contingency in complex design-build projects", Journal of Construction Engineering and Management, $142(2)$, pp. 24-31 (2015).

90. Li, H. and Xu, Z. "Demeulemeester E. Scheduling policies for the stochastic resource leveling problem", Journal of Construction Engineering and Management, 141(2), pp. 78-88 (2014).

91. El-Kholy, A.M. "New aspects in time-cost tradeoff analysis", Journal of Management in Engineering, 31(4), pp. 112-119 (2013). DOI: 10.1061/(ASCE)ME.1943-5479.0000258

92. Yang, I.T., Lin, Y.C., and Lee, H.Y. "Use of support vector regression to improve computational efficiency of stochastic time-cost trade-off", Journal of Construction Engineering and Management, 140(1), pp. 37-49 (2013). DOI: 10.1061/(ASCE)CO.19437862.0000784

93. Perrenoud, A.J., Sullivan, K.T., and Hurtado, K.C. "The effect of project type on risk timing and frequency", Construction Research Congress 2014: Construction in a Global Network, pp. 1831-1840 (2014). DOI: 10.1061/9780784413517.187

94. Park, H., Lee, K.W., Jeong, H.D., and Han S.H. "Effect of institutional risks on the performance of international construction projects", In Construction Research Congress 2014: Construction in a Global Network, pp. 2126-2135 (2014). 
95. Khamooshi, H. and Cioffi, D.F. "Uncertainty in task duration and cost estimates: Fusion of probabilistic forecasts and deterministic scheduling", Journal of Construction Engineering and Management, 139(5), pp. 488-497 (2012). DOI: 10.1061/(ASCE)CO.19437862.0000616

96. Dikmen, I., Birgonul, M.T., Tah, J.H., and Ozer, A.H. "Web-based risk assessment tool using integrated duration-cost influence network model", Journal of Construction Engineering and Management, 138(9), pp. 1023-1034 (2012). DOI: 10.1061/(ASCE)CO.1943-7862.0000547.

97. Barraza, G.A. "Probabilistic estimation and allocation of project time contingency", Journal of Construction Engineering and Management, 137(4), pp. 259-65 (2010).

98. Mohamed, D., Srour, F., Tabra, W., and Zayed, T. "A Prediction model for construction project time contingency", In Construction Research Congress 2009: Building a Sustainable Future, pp. 736-745 (2009). DOI: $10.1061 / 41020(339) 75$

99. Schatteman, D., Herroelen, W., Van de Vonder, S., and Boone, A. "Methodology for integrated risk management and proactive scheduling of construction projects", Journal of Construction Engineering and Management, 134(11), pp. 885-93 (2008).

100. Ökmen, Ö. and Öztaş, A. "Construction project network evaluation with correlated schedule risk analysis model", Journal of Construction Engineering and Management, 134(1), pp. 49-63 (2008).

101. Feng, C.W., Liu, L., and Burns, S.A. "Stochastic construction time-cost trade-off analysis", Journal of Computing in Civil Engineering, 14(2), pp. 117-26 (2000).

102. Mulholland, B. and Christian, J. "Risk assessment in construction schedules", Journal of Construction Engineering and Management, 125(1), pp. 8-15 (1999).

103. Creemers, S. "Minimizing the expected makespan of a project with stochastic activity durations under resource constraints", Journal of Scheduling, 18(3), pp. 263-73 (2015).

104. Rostami, S., Creemers, S., and Leus, R. "New strategies for stochastic resource-constrained project scheduling", Journal of Scheduling, 2017, pp. 1-17 (2017).

105. Fu, N., Lau, H.C., and Varakantham, P. "Robust execution strategies for project scheduling with unreliable resources and stochastic durations", Journal of Scheduling, 18(6), pp. 607-622 (2015).

106. Zhu, G., Bard, J.F., and Yu, G. "A two-stage stochastic programming approach for project planning with uncertain activity durations", Journal of Scheduling, 10(3), pp. 167-80 (2007).

107. Lee, D.E., Lee, H.G., Arditi, D., Yi, C.Y. "An advanced stochastic time-cost tradeoff analysis based on a CPM-guided genetic algorithm", Computer Aided Civil and Infrastructure Engineering, 30, pp. 824-842 (2015).
108. Choi, J., Realff, M.J., and Lee, J.H. "AQ-Learningbased method applied to stochastic resource constrained project scheduling with new project arrivals", International Journal of Robust and Nonlinear Control, 17(13), pp. 1214-31 (2007). DOI: 10.1002/rnc.1164.

109. Zafra-Cabeza, A., Ridao, M.A., and Camacho E.F. "A stochastic predictive control approach to project risk management", IFAC Proceedings Volumes, 38(1), pp. 134-9 (2005).

110. Pontrandolfo, P. "Project duration in stochastic networks by the PERT-path technique", International Journal of Project Management, 18(3), pp. 215-22 (2000).

111. Gong, D. "Optimization of float use in risk analysisbased network scheduling", International Journal of Project Management, 15(3), pp. 187-92 (1997). DOI: 10.1016/S0263-7863(95)00083-6.

112. Mahjoub, A., Pecero Sánchez, J.E., and Trystram, D. "Scheduling with uncertainties on new computing platforms", Computational Optimization and Applications, 48(2), pp. 369-98 (2011).

113. Ahuja, H.N. and Nandakumar, V. "Simulation model to forecast project completion time", Journal of Construction Engineering and Management, 111(4), pp. 325-42 (1985).

114. Bruun, P. "Discussion of scheduling maintenance dredging on a single reach with uncertainty", Journal of Waterway, Port, Coastal, and Ocean Engineering, 118(1), pp. 118-9 (1992).

115. Lansey, K.E. and Menon, H. "Optimal risk-based inspection and dredging scheduling for independent dredge reaches", Journal of Waterway, Port, Coastal, and Ocean Engineering, 119(3), pp. 289-301 (1993). DOI: 10.1061/(ASCE)0733-950X(1993)119:3(289).

116. Ben-Haim, Y. and Laufer, A. "Robust reliability of projects with activity-duration uncertainty", Journal of Construction Engineering and Management, 124(2), pp. 125-32 (1998).

117. Guillaumot, V.M., Durango-Cohen, P.L., and Madanat, S.M. "Adaptive optimization of infrastructure maintenance and inspection decisions under performance model uncertainty", Journal of Infrastructure Systems, 9(4), pp. 133-9 (2003). DOI: 10.1061/(ASCE)1076-0342(2003)9:4(133).

118. Moussa, M., Ruwanpura, J., and Jergeas, G. "CTAN for risk assessments using multilevel stochastic networks", Journal of Construction Engineering and Management, 133(1), pp. 96-101 (2007).

119. Vaziri, K., Carr, P.G., and Nozick, L.K. "Project planning for construction under uncertainty with limited resources", Journal of Construction Engineering and Management, 133(4), pp. 268-276 (2007).

120. Bocchini, P., and Frangopol, D.M. "Connectivitybased optimal scheduling for maintenance of bridge networks", Journal of Engineering Mechanics, 139(6), pp. 760-9 (2011). 
121. Nguyen, L.D., Phan, D.H., and Tang, L.C. "Simulating construction duration for multistory buildings with controlling activities", Journal of Construction Engineering and Management, 139(8), pp. 951-9 (2013). DOI: 10.1061/(ASCE)CO.19437862.0000677 .

122. Ma. G., Wang. A, Li. N., Gu. L., and Ai, Q. "Improved critical chain project management framework for scheduling construction projects", Journal of Construction Engineering and Management, 140(12), pp. 24-31 (2014). DOI: 10.1061/(ASCE)CO.19437862.0000908 .

123. Russell, M.M., Liu, M., and Hsiang, S.M. "Planning for uncertainty: use of structural equation modeling to determine the causal structure of time buffer allocation", Construction Management and Economics, 33(10), pp. 783-98 (2015).

124. Wang, Y., Le, Y., and Dai, J. "Incorporation of alternatives and importance levels in scheduling complex construction programs", Journal of Management in Engineering, 31(6), pp. 11-19 (2014).

125. Ji, X. and Yao, K. "Uncertain project scheduling problem with resource constraints", Journal of Intelligent Manufacturing, 1, pp. 1-6 (2014).

126. Gan, L. and $\mathrm{Xu}$, J. "Control risk for multimode resource-constrained project scheduling problems under hybrid uncertainty", Journal of Management in Engineering, 31(3), pp. 67-74 (2013).

127. Russell, M.M., Liu, M., Howell, G., and Hsiang, S.M. "Case studies of the allocation and reduction of time buffer through use of the last planner system", Journal of Construction Engineering and Management, 141(2), 43-51 (2014). DOI: 10.1061/(ASCE)CO.1943-7862.0000900.

128. Wang, C., Zhang, S., Du, C., Pan, F., and Xue, L. "A real-time online structure-safety analysis approach consistent with dynamic construction schedule of underground caverns", Journal of Construction Engineering and Management, 142(9), 1-12 (2016).

129. Li, Y., Lu, K., and Lu, Y. "Project schedule forecasting for skyscrapers", Journal of Management in Engineering, 2016, pp. 1-38 (2016). DOI: 10.1061/(ASCE)ME.1943-5479.0000498.

130. Artigues, C., Leus, R., and Nobibon, F.T. "Robust optimization for resource-constrained project scheduling with uncertain activity durations", Flexible Services and Manufacturing Journal, 25(1-2), pp. 175-205 (2013).

131. Mawlana, M. and Hammad, A. "Joint probability for evaluating the schedule and cost of stochastic simulation models", Advanced Engineering Informatics, 29(3), pp. 380-95 (2015).

132. Mínguez, R., Conejo, A.J., and García-Bertrand, R. "Reliability and decomposition techniques to solve certain class of stochastic programming problems", Reliability Engineering \& System Safety, 96(2), pp. 314-23 (2011).
133. Likhachev, M. and Stentz, A. "Probabilistic planning with clear preferences on missing information", Artificial Intelligence, 173(5-6), pp. 696-721 (2009).

134. Öztaş, A. and Ökmen, Ö. "Judgmental risk analysis process development in construction projects", Building and Environment, 40(9), pp. 1244-54 (2005).

135. Zwikael, O. and Sadeh, A. "Planning effort as an effective risk management tool", Journal of Operations Management, 25(4), pp. 755-67 (2007). DOI: 10.1016/j.jom.2006.12.001.

136. Li, Z. "Chance constrained planning and scheduling under uncertainty using robust optimization approximation", IFAC-Papers Online, 48(8), pp. 1156-61 (2015).

137. Zhang, L., Huang, Y., Wu, X., and Skibniewski, M.J. "Risk-based estimate for operational safety in complex projects under uncertainty", Applied Soft Computing, 54, pp. 108-20 (2017).

138. Ryu, D.W., Kim, J.I., Suh, S., and Suh, W. "Evaluating risks using simulated annealing and building information modeling", Applied Mathematical Modelling, 39(19), pp. 5925-35 (2015).

139. Dehghan, R. and Ruwanpura, J.Y. "The mechanism of design activity overlapping in construction projects and the time-cost tradeoff function", Procedia Engineering, 14, pp. 1959-65 (2011).

140. Yang, I.T. and Chang, C.Y. "Stochastic resourceconstrained scheduling for repetitive construction projects with uncertain supply of resources and funding", International Journal of Project Management, 23(7), pp. 546-53 (2005).

141. Tabrizi, B.H. and Ghaderi, S.F. "A robust biobjective model for concurrent planning of project scheduling and material procurement", Computers \& Industrial Engineering, 98, pp. 11-29 (2016).

142. AlNasseri, H. and Aulin, R. "Assessing understanding of planning and scheduling theory and practice on construction projects", Engineering Management Journal, 27(2), pp. 58-72 (2015).

143. Herroelen, W. and Leus, R. "Robust and reactive project scheduling: a review and classification of procedures", International Journal of Production Research, 42(8), pp. 1599-620 (2004).

144. Zilberstein, S. and Mouaddib, A.I. "Optimal scheduling of progressive processing tasks", International Journal of Approximate Reasoning, 25(3), pp. 16986 (2000).

145. Gálvez, E.D. and Capuz-Rizo, S.F. "Assessment of global sensitivity analysis methods for project scheduling", Computers \& Industrial Engineering, 93, pp. 110-20 (2016).

146. Lawrence, S.R. and Sewell, E.C. "Heuristic, optimal, static, and dynamic schedules when processing times are uncertain", Journal of Operations Management, 15(1), pp. 71-82 (1997). 
147. Kadipasaoglu, S.N. and Sridharan, V. "Alternative approaches for reducing schedule instability in multistage manufacturing under demand uncertainty", Journal of Operations Management, 13(3), pp. 193211 (1995). DOI: 0.1016/0272-6963(95)00023-L

148. Gong, D. and Rowings, J.E. "Calculation of safe float use in risk-analysis-oriented network scheduling", International Journal of Project Management, 13(3), pp. 187-94 (1995).

149. Rahmani, D., Ramezanian, R., Fattahi, P., and Heydari, M. "A robust optimization model for multiproduct two-stage capacitated production planning under uncertainty", Applied Mathematical Modelling, 37(20), pp. 8957-71 (2013). DOI: $10.1016 /$ j.cie.2015.12.006

150. Shah, R.K. "A new approach for automation of location-based earthwork scheduling in road construction projects", Automation in Construction, 43, pp. 156-69 (2014).

151. Izák, M. Görges, D., and Liu, S. "Stabilization of systems with variable and uncertain sampling period and time delay", Nonlinear Analysis: Hybrid Systems, 4(2), pp. 291-305 (2010).

152. Izák, M. Görges, D., and Liu, S. "Stability and control of systems with uncertain time-varying sampling period and time delay", IFAC Proceedings Volumes, 2008 Dec 31; 41(2), pp. 11514-9 (2008).

153. Tang, O. and Grubbström, R.W. "Planning and replanning the master production schedule under demand uncertainty", International Journal of Production Economics, 78(3), pp. 323-34 (2002).

154. Herroelen, W. and Leus, R. "Project scheduling under uncertainty: Survey and research potentials", European Journal of Operational Research, 165(2), pp. 289-306 (2005).

155. Wang, L., Martin, K., and Bai, S.J. "Realizing value from project implementation under uncertainty: An exploratory study using system dynamics", International Journal of Project Management, 35(3), pp. 41352 (2017). DOI: 10.1016/j.ijproman.2017.01.009.

156. Chang, A., Hatcher, C., and Kim, J. "Temporal boundary objects in megaprojects: Mapping the system with the integrated master schedule", International Journal of Project Management, 13(2013), pp. 323-332 (2013). DOI: 10.1016/j.ijproman.2012.08.007.

157. Arashpour, M., Wakefield, R., Lee, E.W., Chan, R., and Hosseini, M.R. "Analysis of interacting uncertainties in on-site and off-site activities, implications for hybrid construction", International Journal of Project Management, 34(7), pp. 1393-402 (2016). DOI: $10.1016 / 0956-0521(93) 90052-\mathrm{X}$

158. Fiedler, K. "Special conditions for time scheduling of building modernization process", International Journal of Project Management, 5(1), pp. 35-8 (1987).

159. Bushuyev, S.D. and Sochnev, S.V. "Entropy measurement as a project control tool", International Journal of Project Management, 17(6), pp. 343-50 (1999).
160. Zhao, X. and Lee, T.S. "Freezing the master production schedule for material requirements planning systems under demand uncertainty", Journal of $\mathrm{Op}$ erations Management, 11(2), pp. 185-205 (1993).

161. Koo, K.J., Kim, S.K., and Park, H.K. "A simulation approach for a periodic PCR buffer allocation strategy in organizational program management", Automation in Construction, 20(8), pp. 1020-1029 (2011).

162. Sridharan, V. and LaForge, R.L. "The impact of safety stock on schedule instability, cost and service", Journal of Operations Management, 8(4), pp. 327-347 (1998).

163. Alzraiee, H., Zayed, T., and Moselhi, O. "Dynamic planning of construction activities using hybrid simulation", Automation in Construction, 49, pp. 176-992 (2015).

164. Acebes, F., Pajares, J., Galán, J.M., and LópezParedes, A. "A new approach for project control under uncertainty. Going back to the basics", International Journal of Project Management, 32(3), pp. 423-434 (2014).

165. Van Marrewijk, A., Clegg, S.R., and Pitsis, T.S., and Veenswijk, M. "Managing publicprivate megaprojects: Paradoxes, complexity, and project design", International Journal of Project Management, 26(6), pp. 591-600 (2008). DOI: 10.1016/j.ijproman.2007.09.007.

166. Raturi, A.S., Meredith, J.R., McCutcheon, D.M., and Camm, J.D. "Coping with the build-to-forecast environment", Journal of Operations Management, 9(2), pp. 230-249 (1990).

167. Garaix, T., Artigues, C., and Briand, C. "Fast minimum float computation in activity networks under interval uncertainty", Journal of Scheduling, 16(1), pp. 93-103 (2013).

168. Demeulemeester, E. and Herroelen, W. "Introduction to the special issue: project scheduling under uncertainty", Journal of Scheduling, 10(3), pp. 151-152 (2007).

169. Golizadeh, H., Sadeghifam, A.N., Aadal, H., Zaimi, M., and Majid, A. "Automated tool for predicting duration of construction activities in tropical countries", KSCE Journal of Civil Engineering, 20(1), pp. 12-22 ( January 2016).

170. Vujanic, R., Goulart, P., and Morari, M. "Robust optimization of schedules affected by uncertain events", Journal of Optimization Theory and Applications, 171(3), pp. 1033-54 (2016).

171. Lamas, P. and Demeulemeester, E. "A purely proactive scheduling procedure for the resource-constrained project scheduling problem with stochastic activity durations", Journal of Scheduling, 19(4), pp. 409-428 (2016).

172. Jeang, A. "Project management for uncertainty with multiple objectives optimization of time, cost and reliability", International Journal of Production Research, 53(5), pp. 1503-26 (2015). 
173. Ke, H., Liu, H., and Tian, G. "An uncertain random programming model for project scheduling problem", International Journal of Intelligent Systems, $\mathbf{3 0}(1)$, pp. 66-79 (2015).

174. Shtub, A. "The trade-off between the net present cost of a project and the probability to complete it on schedule", Journal of Operations Management, 6(3), pp. $461-70$ (1986).

175. Lambrechts, O., Demeulemeester, E., and Herroelen, W. "Proactive and reactive strategies for resourceconstrained project scheduling with uncertain resource availabilities", Journal of Scheduling, 11(2), pp. 121-36 (2008).

176. Chen, W.T. and Huang, Y.H. "Approximately predicting the cost and duration of school reconstruction projects in Taiwan", Construction Management and Economics, 24(12), pp. 1231-1239 (2006).

177. Gil, N., Tommelein, I.D., and Ballard, G. "Theoretical comparison of alternative delivery systems for projects in unpredictable environments", Construction Management and Economics, 22(5), pp. 495-508 (2004).

178. Abdeddaïm, Y., Asarin, E., and Maler, O. "On optimal scheduling under uncertainty", International Conference on Tools and Algorithms for the Construction and Analysis of Systems, Springer Berlin Heidelberg, pp. 240-253 (2003).

179. Zhu, G., Bard, J.F., and Yu, G. "Disruption management for resource-constrained project scheduling", Journal of the Operational Research Society, 56(4), pp. 365-81 (2005).

180. Ke, H., Wang, L., and Huang, H. "An uncertain model for RCPSP with solution robustness focusing on logistics project schedule", International Journal of e-Navigation and Maritime Economy, 3, pp. 71-83 (2015). DOI: 10.1016/j.enavi.2015.12.007

181. Van de Vonder, S., Demeulemeester, E., and Herroelen, W. "A classification of predictive-reactive project scheduling procedures", Journal of Scheduling, 10(3), pp. 195-207 (2007).

182. Leu, S.S. and Hung, T.H. "A genetic algorithm-based optimal resource-constrained scheduling simulation model", Construction Management \& Economics, 20(2), pp. 131-41 (2002).

183. Ivanov, D., Alexandre, D., and Boris, S. "Applicability of optimal control theory to adaptive supply chain planning and scheduling", Annual Reviews in Control, 36(1), pp. 73-84 (2012).

184. Guo, Z.X., Wong, W.K., Leung, S.Y., Fan, J.T., and Chan, S.F. "Genetic optimization of order scheduling with multiple uncertainties", Expert Systems with Applications, 35(4), pp. 1788-801 (2008).

185. Chtourou, H. and Haouari, M. "A two-stage-priorityrule-based algorithm for robust resource-constrained project scheduling", Computers \& Industrial Engineering, 55(1), pp. 183-94 (2008).
186. Kao, H.P., Wang, B., Dong, J., and Ku, K.C. "An event-driven approach with makespan/cost tradeoff analysis for project portfolio scheduling", Computers in Industry, 57(5), pp. 379-97 (2006).

187. Krajewski, L., Wei, J.C., and Tang, L.L. "Responding to schedule changes in build-to-order supply chains", Journal of Operations Management, 23(5), pp. 452469 (2004). DOI: 10.1016/j.jom.2004.10.006

188. Mohamed, A. and Celik, T. "Knowledge basedsystem for alternative design cost estimating and scheduling", Knowledge-Based Systems, 15(3), pp. 177-88 (2002). DOI: 10.1016/S0950-7051(01)00155-1

189. Mou, J., Gao, L., Guo, Q., and Mu, J. "A hybrid heuristic algorithm for flow shop inverse scheduling problem under a dynamic environment", Cluster Computing, 20(1), pp. 439-53 (2017).

190. Ke, H. "A genetic algorithm-based optimizing approach for project time-cost trade-off with uncertain measure", Journal of Uncertainty Analysis and Applications, 2(1), p. 8 (2014).

191. Chan, L.H., Huang. N., Guo, T., Lu, W., and Skitmore, M. "Optimizing construction planning schedules by virtual prototyping enabled resource analysis", Automation in Construction, 18(7), pp. 912-918 (2009). DOI: 10.1016/j.autcon.2009.04.002

192. Wang, W.C. and Demsetz, L.A. "Model for evaluating networks under correlated uncertaintyNETCOR", Journal of Construction Engineering and Management, 126(6), pp. 458-66 (2000).

193. Ersahin, T., McCabe, B., and Doyle, M. "Monte carlo simulation analysis at Lester B Pearson international airport development project", In Construction Research Congress: Wind of Change: Integration and Innovation, pp. 1-8 (2003).

194. Park, M. and Peña-Mora, F. "Reliability buffering for construction projects", Journal of Construction Engineering and Management, 130(5), pp. 626-37 (2004).

195. Ryu, H.G., Lee, H.S., and Park, M. "Construction planning method using case-based reasoning", Journal of Computing in Civil Engineering, 21(6), pp. 410-22 (2007).

196. Yousefi, S., Hegazy, T., Capuruço, R.A., and Attalla, M. "System of multiple ANNs for online planning of numerous building improvements", Journal of Construction Engineering and Management, 134(5), pp. 342-351 (2008). DOI: 10.1061/(ASCE)07339364(2008)134:5(342).

197. Song, L., Cooper, C., and Lee, S.H. "Real-time simulation for look-ahead scheduling of heavy construction projects", Construction Research Congress 2009: Building a Sustainable Future, pp. 1318-1327 (2009). DOI: 10.1061/41020(339)134

198. Ezeldin, A.S. and Soliman, A. "Hybrid time-cost optimization of nonsocial repetitive construction projects", Journal of Construction Engineering and Management, 135(1), pp. 42-55 (2009). 
199. Francis, A. and Miresco, E. "A generalized time-scale network simulation using chronographic dynamics relations", Computing in Civil Engineering, 2011, pp. 560-568 (2011).

200. Nguyen, L.D., Phan, D.H., and Tang, L.C. "Predicting construction duration with typical construction sequences for high-rise buildings", AEI 2013: Building Solutions for Architectural Engineering, 2013, pp. 387-396 (2013). DOI: 10.1061/9780784412909.037

201. Touran, A. "A mathematical structure for modeling uncertainty in cost, schedule, and escalation factor in a portfolio of projects", Construction Research Congress 2014: Construction in a Global Network, pp. 1743-1751 (2014). DOI: 10.1061/9780784413517.178

202. Ma, G., Gu, L., and Li, N. "Scenario-based proactive robust optimization for critical-chain project scheduling", Journal of Construction Engineering and Management, 141(10) (Oct. 2015).

203. Bi, L., Ren, B., Zhong, D., and Hu, L. "Realtime construction schedule analysis of long-distance diversion tunnels based on litho logical predictions using a Markov process", Journal of Construction Engineering and Management, 141(2) (Feb. 2015).

204. Baqerin, M.H., Shafahi, Y., and Kashani, H. "Application of weibull analysis to evaluate and forecast schedule performance in repetitive projects", Journal of Construction Engineering and Management, 142(2) (Feb. 2016). DOI: 10.1061/(ASCE)CO.19437862.0001040

205. Francis, A. "Simulating uncertainties in construction projects with chronographical scheduling logic", Journal of Construction Engineering and Management, 143(1) (Jan. 2017).

206. Mak, K.L., Lau, J.S., and Wang, X.X. "A genetic scheduling methodology for virtual cellular manufacturing systems: an industrial application", International Journal of Production Research, 43(12), pp. 2423-2450 (2005). DOI: 10.1080100207540500046020

207. Lam, K.C., Ning, X., and Ng, T. "The application of the ant colony optimization algorithm to the construction site layout planning problem", Construction Management and Economics, 25(4), pp. 359-274 (2007). DOI: 10.108010020750500046020

208. McPherson, R.F. and White, K.P. "A framework for developing intelligent real-time scheduling systems", Human Factors and Ergonomics in Manufacturing \& Service Industries, 16(4), pp. 385-408 (2006).

209. Yang, H.L. and Wang, C.S. "Recommender system for software project planning one application of revised CBR algorithm", Expert Systems with Applications, 36(5), pp. 8938-45 (2009).

210. Huang, G.H., Baetz. B.W., and Patry, G.G. "Development of a grey critical path method for construction planning", Engineering Optimization, 28(3) (1997).
211. Rudloff, D. and Schultz, M. "Top risks in oil and gas", Oil and Gas Journal, 13, pp. 175-194 (2016).

212. Ghasemi, S., Yavari, K., Mahmoudvand, R., and Sahabi, B. "Presenting a new method for scrutiny the insurable risk in gas refineries by FMEA", Journal of Economic Policy, 13(7), pp. 1-26 (2015).

213. Najafi, P., Haji, H., and Shahhosseini, V. "Risk quantification in complex and fast projects and impact on the timely completion of the project", International Conference on Management Tools and Techniques, Tehran (2015).

214. Doosti, Y., Khazaei, S., and Rafati, P. "Risk management in the construction of gas refineries", Iranian Conference of Civil Engineering and Its Achievements, Iran (2014).

215. Ardeshir, A., Mohajeri, M., and Amiri, M. "Safety assessment in construction projects based on analytic hierarchy process and grey fuzzy methods", Iran Occupational Health, 11(2), pp. 87-98 (2014).

216. Bordbar, A. and Sayebani, M. "Identification and allocation of risks in construction projects", First National Conference on Construction Project Management, Tehran (2013).

217. Amanatyazdi, L. and Moharramnejad, N. "Risk management in Iranian Oil Company", Journal of Environmental Studies, 39(20), pp. 61-72 (2013).

218. Hamzei, H. and Alamtabriz, A. "Project risk assessment by the new hybrid method of incorporation PMBOK and FMEA", Journal of Industrial Management Studies, 2012, pp.1-19 (2012).

219. Attarzadeh, M., Chua, D.K., and Michael, B. "Risk management of Asalouye desalination project", Fifth International Symposium on Uncertainty Modeling and Analysis (2011).

220. Soltani, R., Ebrahim-Zadeh, M., and Halvani, G.H. "Risk assessment in Shiraz refinery by FMEA method", Journal of Iran Occupational Medicine, 3(2), pp. 16-23 (2011).

221. Jalaee, F. and Mahdaviparsa, A. "Risk management in Iranian construction projects", 6th International Conference on Project Management, Tehran (2010).

\section{Biographies}

Abbas Naderpour is a $\mathrm{PhD}$ candidate at Islamic Azad University, Central Tehran Branch. He has MSc degree in Construction Management from Islamic Azad University, Tehran Science and Research Branch. He has a broad background in Civil Engineering. He is a member of the Project Management Institute (PMI) and has 15 years of practical experience in construction management in National Iranian Gas Company (NIGC). His research Interests are earned value management, project resource allocation, project risk assessment, soft computing, artificial intelligence, 
and fuzzy expert systems.

Javad Majrouhi Sardroud holds $\mathrm{PhD}$ degree in Construction Management from Kingston University, London, and MSc degree in Structural Engineering from Tabriz University, Iran. He also has 20 years of practical experience in construction management, including contracting, consulting, and ownership. He has been an active academic member at Azad University in Iran since 2002 and, currently, he is an Assistant Professor in the Faculty of Engineering at Central Tehran Branch, Islamic Azad University. His main research interests span the disciplines of automation and construction including sustainable construction. His research and teaching interests include automation in construction management, building information modeling, operation research, and green building.

Massood Mofid is a Professor of Structural and Earthquake Engineering at Sharif University of Technology, Tehran, Iran. He received his BSc degree from University of Tehran. Moreover, he received his MSc and $\mathrm{PhD}$ degrees from Rice University. His research interests are in the area of structural analysis and structural dynamics.
Yiannis Xenidis taught in the Department of Spatial Planning and Development in AUTH during 20052008. Currently, he is a faculty member (Assistant Professor) in the Department of Civil Engineering at AUTH and a tutor/advisor in the School of Science and Technology at the Hellenic Open University. He is the author of several peer reviewed papers in scientific journals and conferences and has contributed, upon invitation, to book chapters in several publications. His research interests and teaching activities include resilient systems, risk analysis and decision-making theory, infrastructure investments and development, cost and schedule management in civil engineering projects, project management, construction management, and human resources management.

Towhid Pour Rostam holds a PhD degree in Construction Management from University Kebangsaan Malaysia (UKM). He obtained his BSc and MSc in 1996 and 1999, respectively, from the Islamic Azad University in Iran. He is currently a senior academic member and lecturer in the Faculty of Engineering at Islamic Azad University. His research interests are project risk management, time and cost trade-off, and other construction management issues. 